\title{
İmâm Mâlik'ten Nakledildikleri Halde Matbû' Muvatta' Nüshalarında Yer Almayan Sahîhayn Rivâyetleri Üzerine Bir Araştırma
}

\author{
Dr. Öğr. Üyesi Üzeyir DURMUŞ*
}

Atıf / @C- Durmuş, Ü. (2018). İmâm Mâlik'ten Nakledildikleri Halde Matbû' Muvatta' Nüshalarında Yer Almayan Sahîhayn Rivâyetleri Üzerine Bir Araştırma, Çukurova Üniversitesi İlahiyat Fakültesi Dergisi, 18 (2), 796-824.

Öz- Imâm Mâlik'in Muvatta'ı ve Muvatta' dışındaki rivâyetleri, Buhârî ve Müslim'in el-Câmi'u's-sahîh'lerinin önemli kaynaklarındandır. Buhârî Mâlik'ten tekrarsız 416, Müslim ise 352 rivâyet nakletmiştir. Buhârî'nin 29, Müslim'in 19 rivâyeti Muvatta'ın matbû' nüshalarında yer almamaktadır. Bu rivâyetlerin 8 tanesi müttefekun aleyhtir; 21 tanesi sadece Buhârî, 11 tanesi ise sadece Müslim tarafından rivâyet edilmiştir. Bu makâlede, belirtilen rivâyetlerin tespit ve tahrîci yapılarak günümüze ulaşamayan Muvatta’ nüshalarında bulunup bulunmadıkları, Buhârî ve Müslim'den önceki muhaddislerce Mâlik'e istinâd eden senedlerle rivâyet edilip edilmedikleri gibi konular açıklığa kavuşturulmaya çalışılmıştır. Yapılan araştırma neticesinde, ilgili rivâyetlerin Mâlik'in 16 ayrı talebesinden nakledildikleri, 38 tanesinin Muvatta'ın bilinen nüshalarında yer almadığı, 16 tanesinin Mâlik'ten önceki muhaddislerce de rivâyet edildiği, 32 tanesinin merfû' 8 tanesinin mevkûf olduğu ve çeşitli konulara ait hadislerden oluştukları tespit edilerek tablolarla gösterilmiş; böylece özelde Sahîhayn ve Muvatta' genelde ise Sahîhayn ve Mâlik'in rivâyetleri arasındaki ilişkinin bir boyutu ortaya konulmaya çalışılmıştır.

Anahtar sözcükler- Hadis, Buhârî, Müslim, Mâlik, el-Câmi'u's-ṣaḥị̂, elMuvatta'.

\section{$\S \S \S$}

\footnotetext{
* Çanakkale Onsekiz Mart Üniversitesi İlahiyat Fakültesi Hadis Anabilim Dalı uzeyirdurmus@comu.edu.tr ORCID ID 0000-0003-1776-6160
} 


\section{GíRiş}

Buhârî ve Müslim'in el-Câmi'u's-sahîh'lerinde İmâm Mâlik'ten nakledilen çok sayıda rivâyet bulunmaktadır. Bunların tespit, tahrîc ve değerlendirmesine dair tarafımızdan iki makale kaleme alınmıştır. ${ }^{1} \mathrm{Bu}$ makalelerde Buhârî'nin 416 (tekrarlarla birlikte 696), ${ }^{2}$ Müslim'in 352 (tekrarlarla birlikte 397) rivâyeti Mâlik'e dayanan senedlerle el-Câmi'u's-sahîh'lerinde aktardığı; Buhârî'nin 29 (tekrarlarıyla 35), Müslim'in ise 19 (tekrarıyla 20) rivâyetinin -bir kısmı tam bir kısmı ise eksik olarak günümüze ulaşan- Muvatta' nüshalarının matbû' versiyonlarında yer almadığı ortaya konulmuştur. Bu çalışmada ise, Buhârî ve Müslim tarafından nakledildikleri halde matbû' Muvatta' nüshalarında yer almadığı tespit edilen rivâyetler ele alınacak; ilgili rivâyetlerin Muvatta'ın hangi râvîlerinden nakledildiği, Muvatta'ın matbû' olmayan nüshalarında yer alıp almadıkları, Muvatta' dışında İmâm Mâlik'in naklettiği rivâyetlerden olma intimalleri konularında araştırma sonuçları dermeyan edilecektir. Böylece özelde Sahîhayn ve Muvatta', genelde ise Sahîhayn ve Mâlik'in rivâyetleri arasındaki ilişkiyi ortaya koymak amacıyla üç makâle olarak tasarlanan bu seri tamamlanacaktır.

Makâleye konu olan rivâyetleri tespit etmede esas alınan matbû' Muvatta' nüshaları şunlardır:

1. Ali b. Ziyâd el-Absî (ö. 183/799) nüshası. Muhammed el-Şâzelî enNüfeyr'in tahkîkiyle Beyrût'ta Dârü'l-garbi'l-İslâmî tarafından 1980 yılında neşredilen bu nüsha; dahâyâ, akîka, sayd ve zebâih konularını içeren Mâlik'in fetvaları dâhil 159 rivâyetten oluşan eksik bir nüshadır.

2. Muhammed b. Hasan eş-Şeybânî (ö. 189/805) nüshası. Abdülvehhâb Abdüllatîf'in tahkîkiyle Kâhire'de Lecnetü inyâi't-türâs tarafından 1994 yılında yılında neşredilen bu nüshâ tam olup 1008 rivâyet ihtivâ etmektedir.

3. Abdurrahmân b. Kâsım el-Utakî (ö. 191/806) nüshası. Bu rivâyetin tam metni olmasa da onu ihtisâr ederek sadece merfû' rivâyetlerini Mâlik'in

\footnotetext{
1 Bk. Üzeyir Durmuş, “ímâm Müslim'in Sahîh'ine Kaynaklık Bakımından İmâm Mâlik'in Muvatta’sı (Tahrîc, Mukâyese ve Tahlîl)", Abant İzzet Baysal Üniversitesi Illahiyat Fakültesi Dergisi 6/11 (Haziran 2018), 58-90. "İmâm Buhârî'nin Sahîh'ine Kaynaklık Bakımından İmâm Mâlik'in Muvatta'sı (Tahrîc, Mukâyese ve Tahlîl)" adlı ikinci makâle ise yayınlanma aşamasındadır.

2 Fuad Sezgin bu sayıyı, yaklaşık 300 hadisin 600 kadar yerde tekrar edildiği şeklinde vermektedir. Bk. Fuad Sezgin, Buhârînin Kaynakları (İstanbul: İbrahim Horoz Basımevi, 1956), 305.
} 
hocalarına göre mu'cem tarzında biraraya toplayan Kâbisî'nin el-Mulahhas li müsnedi'l-Muvatta' adlı eseri günümüze tam olarak ulaşmıştır. Bu eser Ali İbrâhîm Mustafâ'nın tahkîkiyle Beyrût'ta Dârü'l-kütübi'l-ilmiyye tarafından 2008 yılında neşredilmiş olup 529 rivâyet içermektedir. Başka baskıları da bulunmaktadır.

4. Abdullâh b. Vehb el-Mısrî (ö. 197/813) nüshası. Mikloş Muranyi'nin tahkîkiyle Beyrût'ta Dârü'l-garbi'l-İslâmî tarafından 2002 yılında bu nüshânın 199 rivâyet içeren bir bölümü Kitâbü'l-muhârebe mine'l-Muvatta' adıyla neşredilmiştir.

5. Abdullâh b. Mesleme el-Ka'nebî (ö. 221/836) nüshası. Abdülmecîd Türkî'nin tahkîkiyle Beyrût'ta Dârü'l-garbi'l-İslâmî tarafından 1999 yılında neşredilen bu nüshada 696 rivâyet bulunmaktadır.

6. Yahyâ b. Yahyâ el-Leysî (ö. 234/849) nüshası. Muhammed Fuâd Abdülbaki'nin tahkîkiyle Kâhire'de Dârü'l-hadîs tarafından 2005 yılında neşredilen versiyonunu kullandığımız bu tam nüshanın farklı sayım metotlarına göre rivâyet sayısı değişmektedir. Bir sayıma göre Mâlik'in görüşleriyle birlikte 1823 rivâyet içermektedir.

7. Süveyd b. Saîd el-Hadesânî (ö. 240/854) nüshası. Abdülmecîd Türkî'nin tahkîkiyle Beyrût'ta Dârü'l-garbi'l-İslâmî tarafından 1994 yılında neşredilen bu nüsha 820 rivâyet intivâ etmektedir.

8. Ebû Mus'ab Ahmed b. Ebû Bekr ez-Zührî (ö. 242/857) nüshası. Beşşâr Avvâd Ma'rûf ve Mahmûd Muhammed Halîl'in tahkîkiyle Beyrût'ta Müessesetü'r-risâle tarafından 1998 yılında neşredilen bu nüsha Mâlik'in görüşleriyle birlikte 3069 rivâyetten oluşmaktadır. ${ }^{3}$

Burada, gerek bir kısmı eksik olan bu nüshalarda yer alan diğer bazı rivâyetleri gerekse başka nüshalardaki farklı rivâyetleri tespit açısından önemli olan şu üç çalışma da zikredilmelidir: ${ }^{4}$

3 Yahyâ b. Abdullâh b. Bükeyr nüshasının İbn Tûmert tarafından tarafından ilk râvîsine kadar senedleri çıkarılmış şeklinin de geçen yüzyılın başında bir baskısı yapılmıştır. Ancak modern bir baskısına ulaşılamadığı için bu eserden faydalanılamadı. Bk. Arif Aytekin, "İbn Tûmert”, Türkiye Diyanet Vakfı İslâm Ansiklopedisi (Ankara: TDV Yayınları, 1999), 20: 427.

4 Detaylı bilgi için bk. Ebubekir Sifil, Muvatta Nüshaları Muhteva Analizi (İstanbul: Rihle Kitap, 2017), 162-180. 
1. Abdurrahmân b. Abdullâh el-Cevherî'nin (ö. 381/991) Müsnedü'lMuvatta'ı. Cevherî, bu çalışmasında 12 Muvatta' nüshasından faydalandığını ve bu nüshalardaki rivâyetlerin çoğunu eserine aldığını belirtmektedir. Faydalandığını belirttiği nüshaların sahipleri şunlardır: İbn Vehb, İbnü’l-Kâsım, Ka'nebî, Tinnîsî, Ma'n b. Îsâ, Saîd b. Ufeyr, İ̉n Bukeyr, Ebû Mus'ab, Mus'ab b. Abdullâh, İbnü'l-Mübârek, Süleymân b. Bürd ve Yahyâ b. Yahyâ elEndelüsî. ${ }^{5}$ Görüldüğü üzere bu 12 nüshadan 7 tanesi yukarıdakilerden farklıdır.

2. Dârekutnî'nin (ö. 385/995) Ehâdîsü'l-Muvatta'ı. Dârekutnî bu eserinde farklı Muvatta' nüshalarındaki rivâyetleri Mâlik'in hocalarına göre sıralamaktadır. Hadisleri, sadece hatırlanmalarını sağlayacak birkaç kelimeyle zikreden Dârekutnî bu eserinde 636 rivâyete yer verdiğini ifade etmektedir. ${ }^{6}$

3. İbn Abdilber'in (ö. 463/1073) Yahyâ b. Yahyâ el-Endelüsî nüshasındaki merfû' rivâyetleri tecrîd ettiği et-Tekassîsi. Bu eserin sonunda Yahyâ nüshasında bulunmayan fakat başka nüshalarda yer alan 67 rivâyet sıralanmaktadır. ${ }^{7}$ Böylece, günümüze ulaşamayan bazı Muvatta' nüshaları hakkında fikir edinilmesine katkı sağlamaktadır.

Bu makâlede yukarıdaki 8 matbû' Muvatta' nüsha esas alınacak fakat yeri geldikçe bütünüyle gözden geçirilmiş olan bu 3 esere de atıfta bulunulacaktır.

\section{MUVATTA' NÜSHALARINDA BULUNMAYAN RIVÂYETLER}

Matbû' Muvatta' nüshalarında yer almayan 48 Sahîhayn rivâyetinin 8 tanesi Buhârî ve Müslim, 21 tanesi sadece Buhârî, 11 tanesi de sadece Müslim tarafından nakledilmektedir. Dolayısıyla 40 rivâyet sözkonusudur.

\subsection{MÜTTEFEKUN ALEYH RIVÂYETLER}

Şeyhayn'ın Mâlik'ten rivâyetleri kapsamında müttefekun aleyh olarak nakledilen fakat mevcût ve bilinen Muvatta' nüshalarında bulunmayan 8 hadis olup şunlardır:

\footnotetext{
5 Abdurrahmân b. Abdullâh el-Cevherî, Müsnedü'l-Muvatta' (Beyrût: Dârü'l-garbi'l-Islâmî, 1997), 633.

${ }^{6}$ Ali b. Ömer ed-Dârekutnî, Ehâdîsü'l-Muvatta' (Şârika: Mektebetü ehli'l-hadîs, ts.), 226.

7 Yûsuf b. Abdilberr en-Nemerî, et-Tekassî (Kuveyt: el-Va'yü'l-İslâmî, 2012), 523-562. Ebû Bekir Sifil, çalışmasında daha eski bir nüshayı kullandığını ve onda 68 rivâyet bulunduğunu kaydetmektedir. Bk. Sifil, Muvatta Nüshaları Muhteva Analizi, 165.
} 


\subsubsection{Birinci Rivâyet}

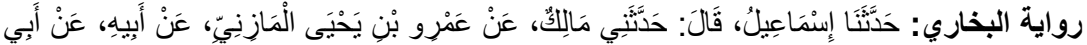

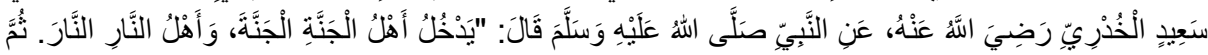

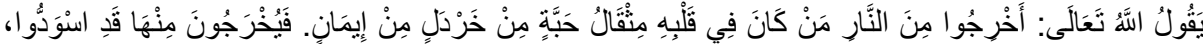

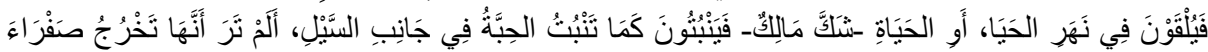

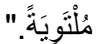

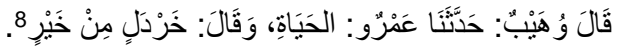

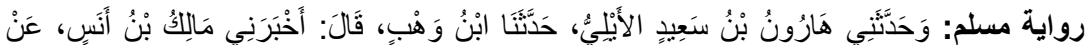

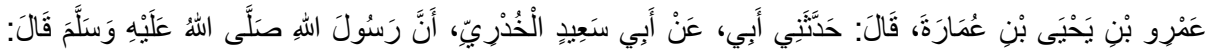

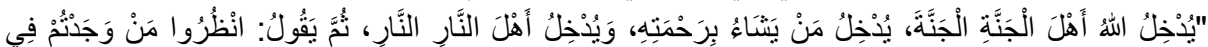

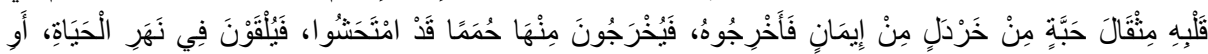

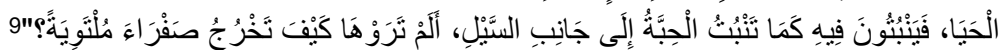

Mâlik'in talebeleri İbn Vehb ve İsmâîl'den nakledilen bu rivâyet, Sahîhayn'dan önce telif edilen ${ }^{10}$ hadis kitaplarında Mâlik'e dayanan senedlerle bulunamamıştır.

\subsection{2. İkinci Rivâyet}

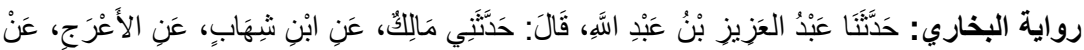

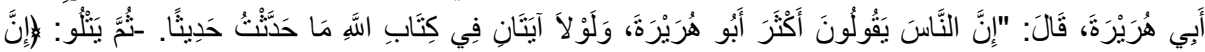

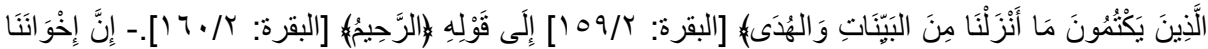

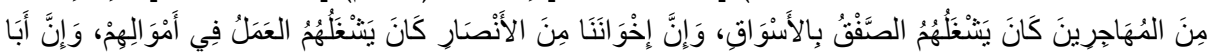

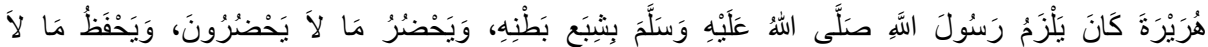

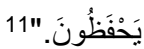

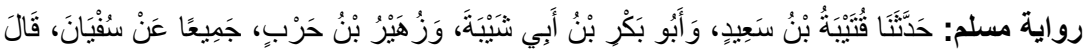

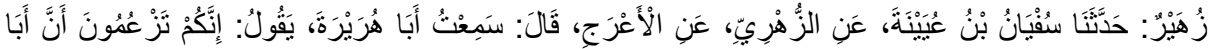

8 Buhârî, "Îmân", 15 (22).

9 Müslim, "Îmân", 304 (184).

${ }^{10} \mathrm{Bu}$ kapsamda, yaşadığı zaman itibariyle Mâlik'ten rivâyette bulunma intimali bulunan ve Şeyhayn'dan önce vefât eden Ma'mer b. Râşid'in (ö. 153/770) el-Câmi', Ebû Yûsuf (ö. 182/798) ve Muhammed'in (ö. 189/805) el-Âsâr, Ebû Dâvûd et-Tayâlisî (ö. 204/819) ve Şâfiî̉nin (ö. 204/819) el-Müsned, Abdürrezzâk es-San'ânînnin (ö. 211/826) el-Emâlî ve el-Musannef, Humeydînnin (ö. 219/834) el-Müsned, Saîd b. Mansûr'un (ö. 227/842) es-Sünen, İbnü'l-Ca 'd'ın (ö. 228/843) el-Müsned, İbn Ebî Şeybe'nin (ö. 235/849) el-Edeb, el-Müsned ve el-Musannef, İshâk b. Râhuye'nin (ö. 238/853) el-Müsned, Ahmed b. Hanbel'in (ö. 241/855) el-Müsned, İbn Zenceveyh'in (ö. 251/865) el-Emvâl ve Dârimînnin (ö. 255/869) es-Sünen'inde ve bir kısım tâlî eserlerde araştırma yapılııştır. "Sahîhayn'dan önce te'lîf edilen" ifâdesi, ilerleyen bölümlerde de aynı kapsamda kullanılacaktır.

${ }_{11}$ Buhârî, "lilim”, 42 (118). 


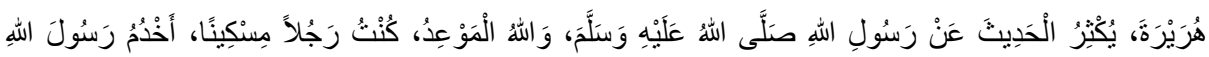

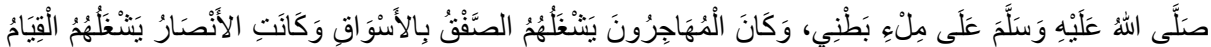

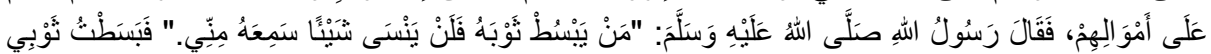

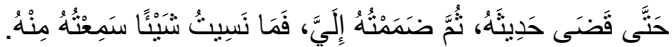

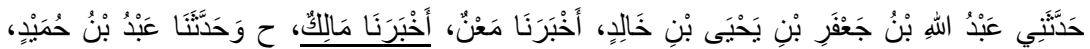

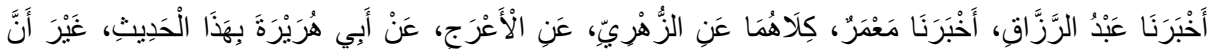

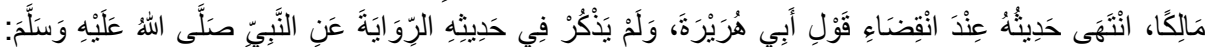

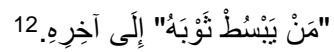

Mâlik'in talebeleri Abdülazîz b. Abdullâh ve Ma'n'dan nakledilen bu rivâyetin varlığına Ahmed b. Hanbel'in Müsned'inde Mâlik'in talebesi İshâk b. Îsâ tarikinden bir rivâyetle işâret olunmaktadır. ${ }^{13}$

\subsection{3. Üçüncü Rivâyet}

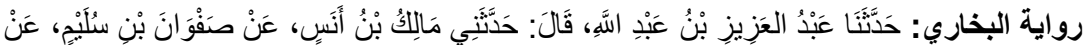

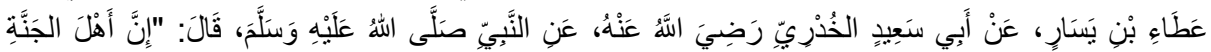

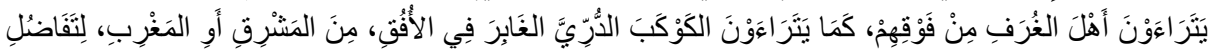

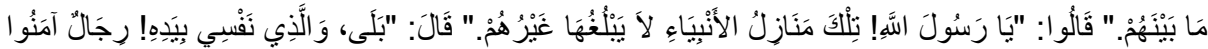

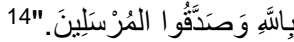

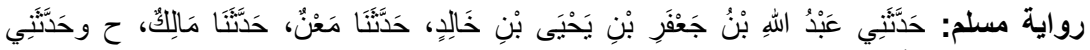

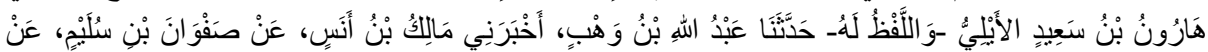

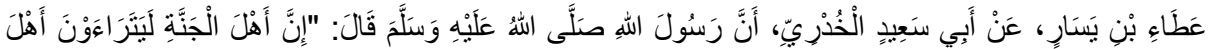

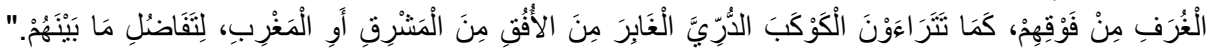

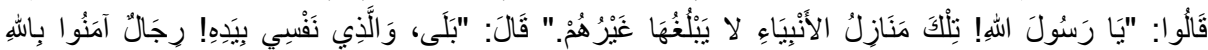

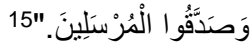

Mâlik'in talebeleri Abdülazîz b. Abdullâh, Ma'n ve İbn Vehb'den nakledilen bu rivâyet, Sahîhayn'dan önce telif edilen hadis kitaplarında Mâlik'e dayanan senedlerle bulunamamıştır.

\subsubsection{Dördüncü Rivâyet}

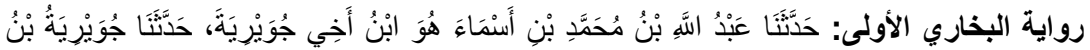

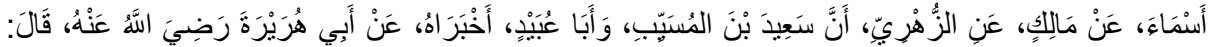

12 Müslim, "Îmân", 159 (2492).

13 Ahmed b. Hanbel, Müsned, 12: 221 (7276).

14 Buhârî, "Bed'ü'l-halk", 8 (3256).

15 Müslim, “Cennet”, 11 (2831). 


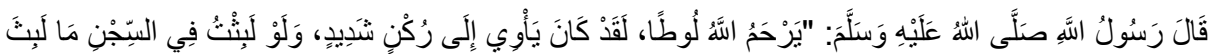

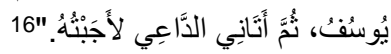

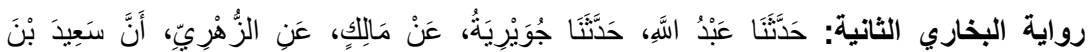

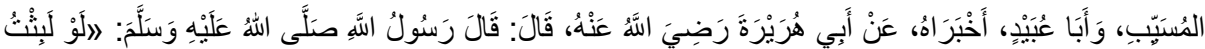

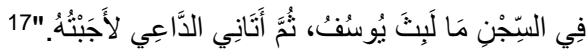

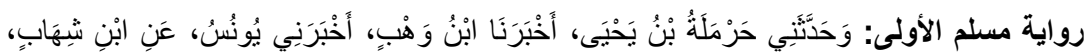

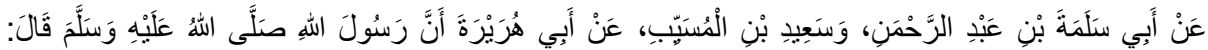

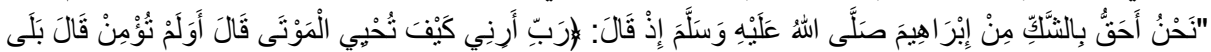

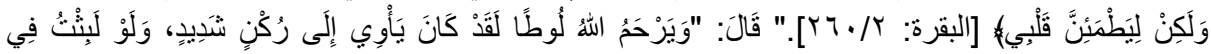

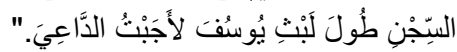

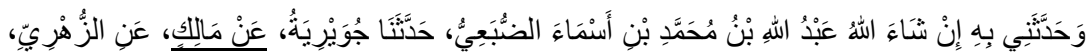

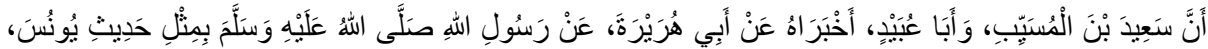

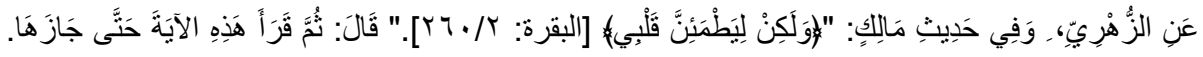

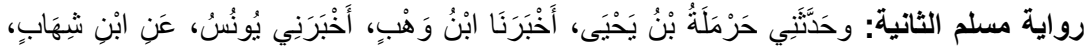

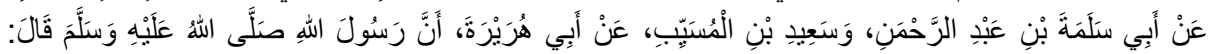

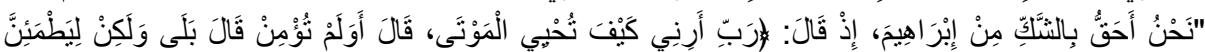

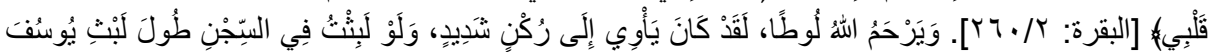

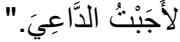

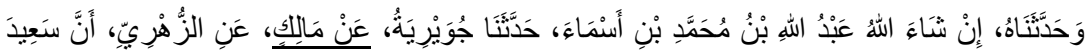

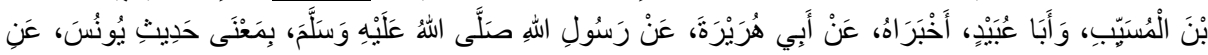
الزَّهُ هْرِيّ. 19

Mâlik'in talebesi Cüveyriye'den nakledilen bu rivâyet, Sahîhayn'dan önce telif edilen hadis kitaplarında Mâlik'e dayanan senedlerle bulunamamıştır.

\subsubsection{Beşinci Rivâyet}

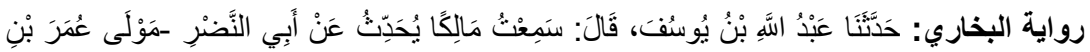

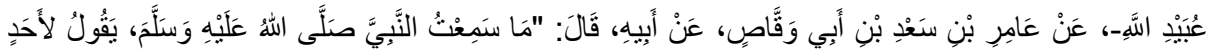

\footnotetext{
16 Buhârî, "Ehâdîsü'l-enbiyâ", 19 (3387).

17 Buhârî, "Ta'bîr", 9 (6992).

18 Müslim, "Îmân", 238 (151).

19 Müslim, "Fedâil", 152 (151).
} 


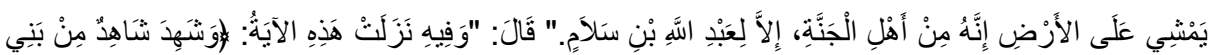

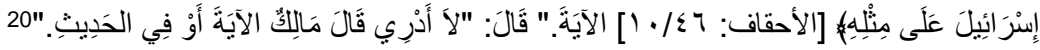

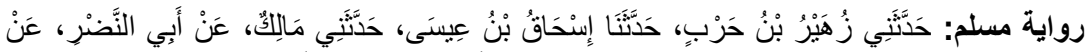

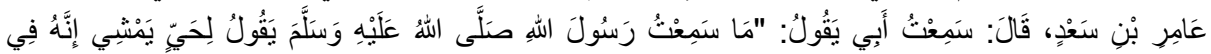

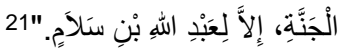

Mâlik'in talebeleri Abdülazîz $b$. Yûsuf ve İshâk $b$. Îsâ'dan nakledilen bu rivâyet, Ahmed b. Hanbel'in Müsnedinde de Mâlik'in talebesi İshâk b. Îsâ tarikinden aynı senedle rivâyet edilmiştir. ${ }^{22}$

\subsubsection{Altıncı Rivâyet}

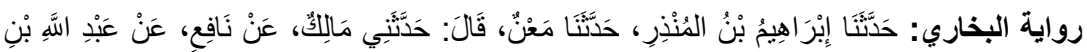

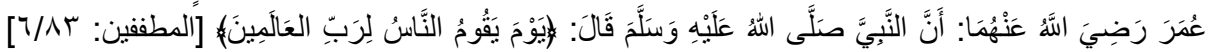

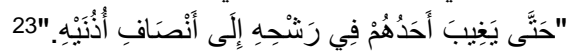

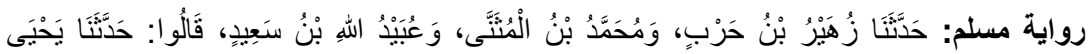

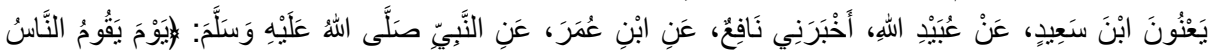

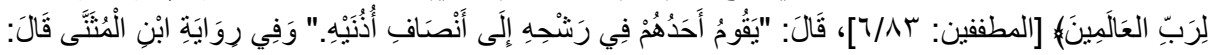

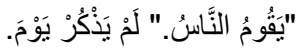

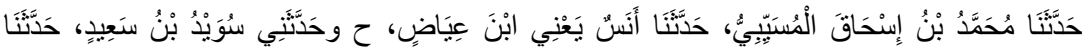

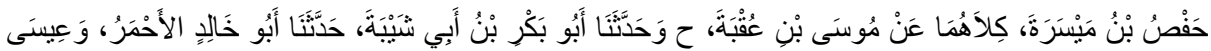

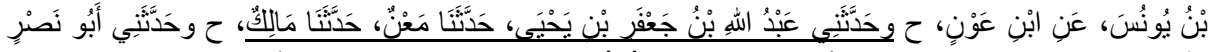

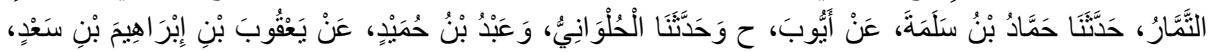

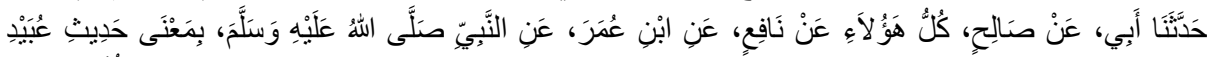

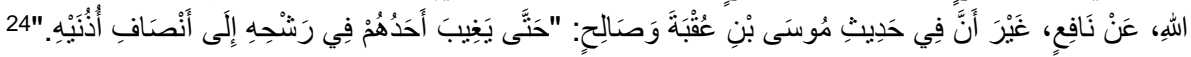

Mâlik'in talebesi Ma'n'dan nakledilen bu rivâyet, Sahîhayn'dan önce telif edilen hadis kitaplarında Mâlik'e dayanan senedlerle bulunamamıştır.

\subsubsection{Yedinci Rivâyet}

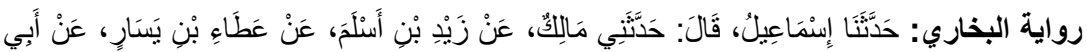

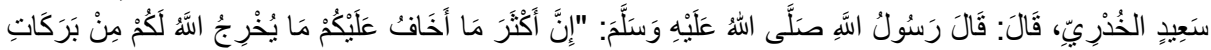

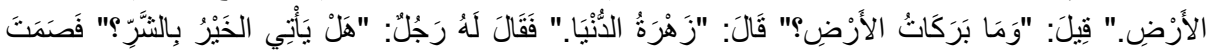

20 Buhârî, "Menâkıbu'l-Ensâr", 19 (3812).

${ }^{21}$ Müslim, "Fedâilü's-sahâbe", 147 (2483).

${ }^{22}$ Ahmed b. Hanbel, Müsned, 3: 59 (1453).

${ }^{23}$ Buhârî, "Tefsîr"/Muttaffifîn", 1 (4938).

${ }^{24}$ Müslim, "Cennet", 60 (2862). 


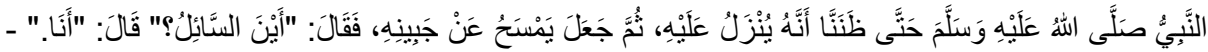

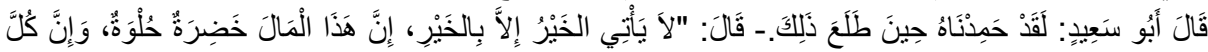

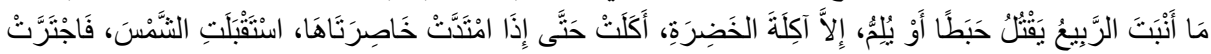

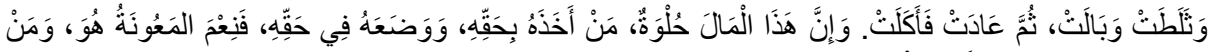

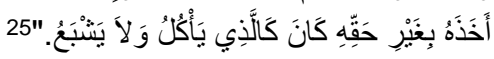

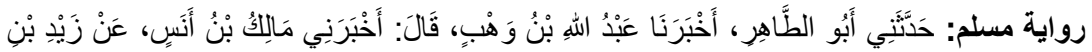

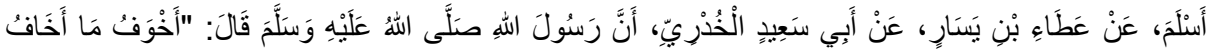

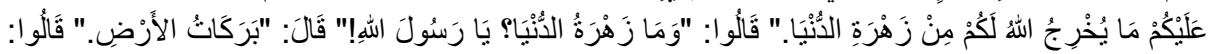

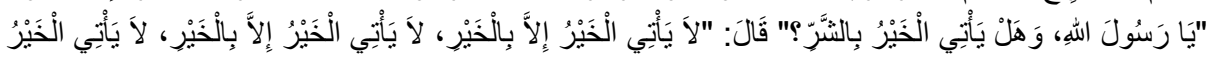

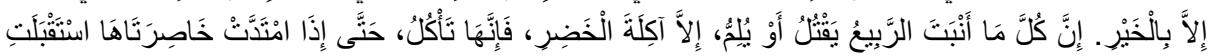

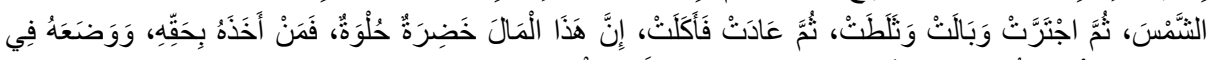

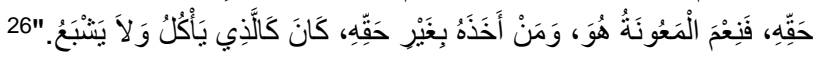

Mâlik'in talebesi İsmâîl ve İbn Vehb'den nakledilen bu rivâyet, Sahîhayn'dan önce telif edilen hadis kitaplarında Mâlik'e dayanan senedlerle bulunamamıştır.

\subsubsection{Sekizinci Rivâyet}

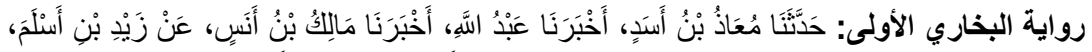

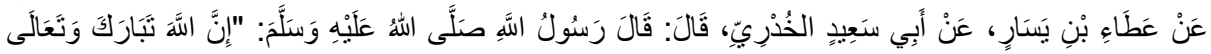

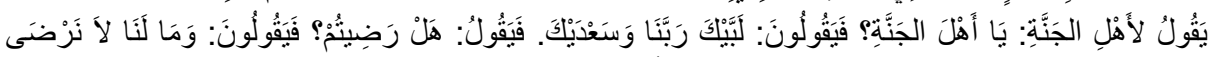

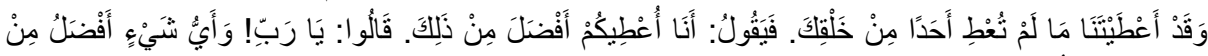

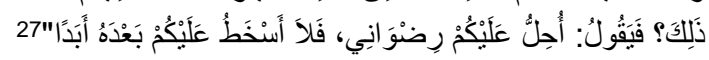

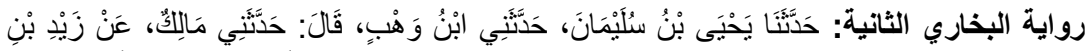

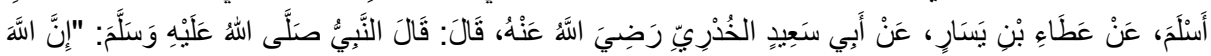

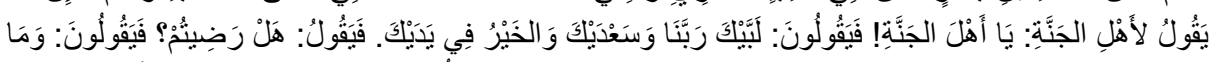

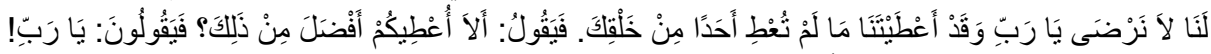

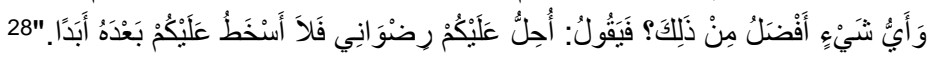

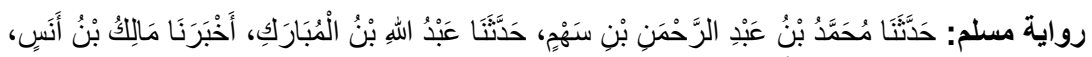

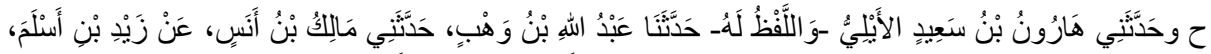

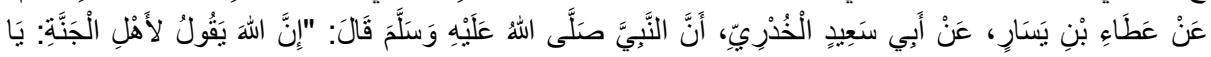

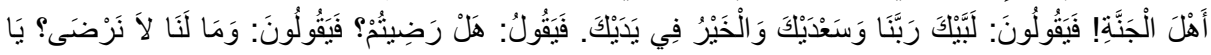

\footnotetext{
25 Buhârî, "Rikâk", 7 (6427).

26 Müslim, "Zekât", 122 (1052).

27 Buhârî, "Rikâk", 51 (6549).

28 Buhârî, "Tevhîd", 38 (7518).
} 


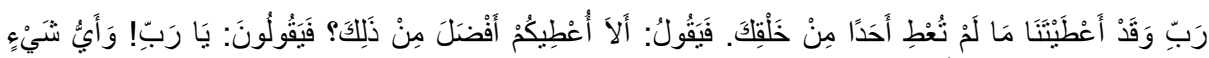

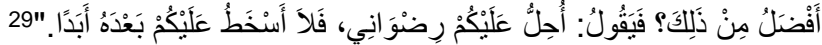

Mâlik'in talebeleri İbn Vehb ve İbnü'l-Mübârek'ten nakledilen bu rivâyet, Ahmed b. Hanbel'in Müsned'inde de Mâlik'in talebesi İbn Vehb tarikinden aynı senedle rivâyet edilmiştir. ${ }^{30}$

\subsection{SADECE BUHÂRî'NIN NAKLETTIĞi RIVÂYETLER}

Şeyhayn'ın Mâlik'ten rivâyetleri kapsamında sadece Sahîh-i Buhârî'de yer alan fakat mevcût ve bilinen Muvatta' nüshalarında bulunmayan 21 hadis vardır. Bu hadisler şunlardır:

\subsubsection{Birinci Rivâyet}

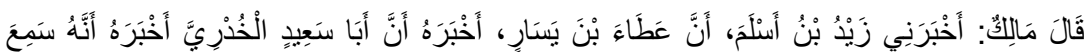

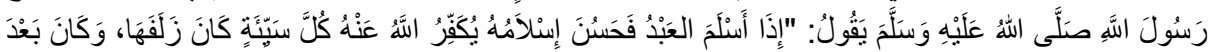

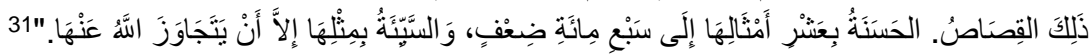

Mâlik'ten muallak olarak nakledilen bu rivâyet, Sahîhayn'dan önce telif edilen hadis kitaplarında Mâlik'e dayanan senedlerle bulunamamıştır.

\subsection{2. İkinci Rivâyet}

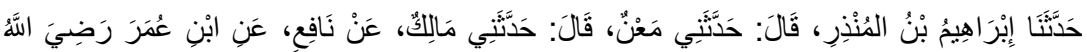

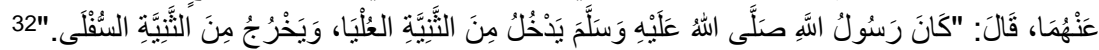

Mâlik'in talebesi Ma'n'dan nakledilen bu rivâyet, Sahîhayn'dan önce telif edilen hadis kitaplarında Mâlik'e dayanan senedlerle bulunamamıştır.

\subsection{3. Üçüncü Rivâyet}

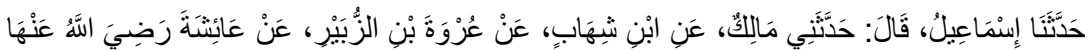

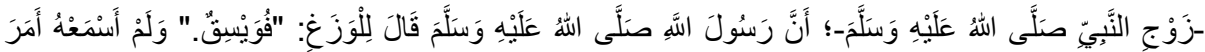

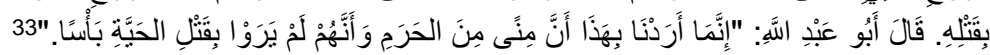

Mâlik'in talebesi İsmâîl'den nakledilen bu rivâyet, Sahîhayn'dan önce telif edilen hadis kitaplarında Mâlik'e dayanan senedlerle bulunamamıştır.

\footnotetext{
29 Müslim, "Cennet”, 9 (2829).

30 Ahmed b. Hanbel, Müsned, 18: 348-349 (11835).

31 Buhârî, "Îmân", 31 (41).

32 Buhârî, "Hac", 40 (1575).

33 Buhârî, "Cezâü's-sayd”, 7 (1831).
} 


\subsubsection{Dördüncü Rivâyet}

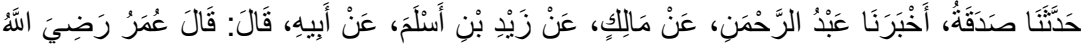

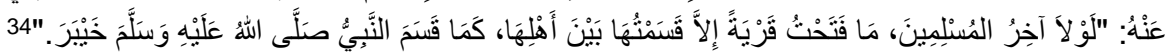

$$
\text { روايته الثانية مثلها.35 }
$$

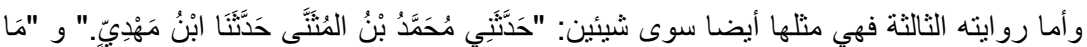

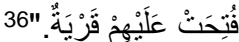

Mâlik'in talebesi İbn Mehdî'den nakledilen bu rivâyet, Ahmed b. Hanbel'in Müsned'inde de aynı sened ve metinle rivâyet edilmiştir. ${ }^{37}$

\subsubsection{Beşinci Rivâyet}

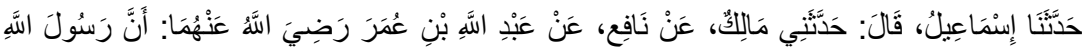

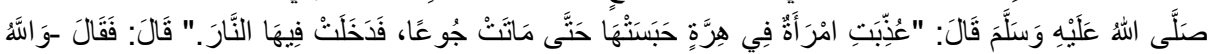

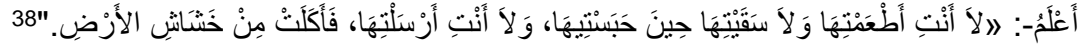

Mâlik'in talebesi İsmâîl'den nakledilen bu rivâyet, Abd b. Humeyd'in Müntehab'ında da aynı sened ve benzer metinle Mâlik'in diğer bir talebesi elHakem b. el-Mübârek tarîkiyle rivâyet edilmiştir. ${ }^{39}$ İbn Abdilber ve (açıkça belirtmeseler de) ondan naklen Cevherî ve Dârekutnî, bu rivâyetin bu senedle sadece Ma'n'ın Muvatta' nüshasında yer aldığını kaydetmektedirler. İbn Abdilber'in metni yukarıdaki metne oldukça yakındır. ${ }^{40}$

\subsubsection{Altıncı Rivâyet}

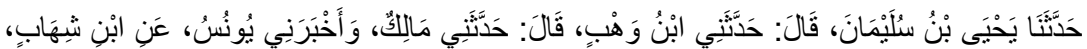

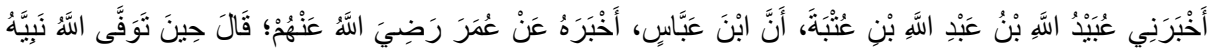

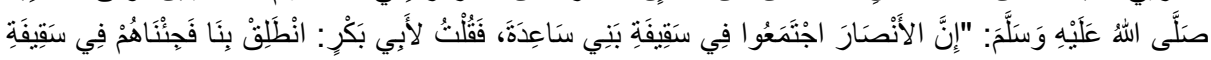
بَنِي سنَاعِدَة.

\footnotetext{
34 Buhârî, "Müzâraa”, 14 (2334).

35 Buhârî, "Fardu'l-humus", 9 (3125).

36 Buhârî, "Megâzî", 38 (4236).

37 Ahmed b. Hanbel, Müsned, 1: 381-382 (284).

38 Buhârî, "Müsâkât", 9 (2365).

39 Abd b. Humeyd, el-Müntehab min Müsnedi Abd b. Humeyd, 2: 33 (787).

40 İbn Abdilber, et-Tekassî, 539-540; Cevherî, Müsnedü'l-Muvatta, 539-540; Dârekutnî, Ehâdîsü'lMuvatta', 154.

41 Buhârî, "Mezâlim", 19 (2462).
} 
Mâlik'in talebesi İbn Vehb'den nakledilen bu rivâyet, Ahmed b. Hanbel'in Müsned'inde de aynı sened ve çok uzun bir metinle İshâk b. Îsâ tarîkiyle rivâyet edilmiştir. ${ }^{42} \mathrm{Bu}$ uzun metnin bir bölümü 19. hadiste gelecektir.

\subsubsection{Yedinci Rivâyet}

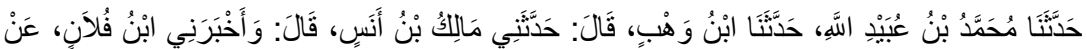

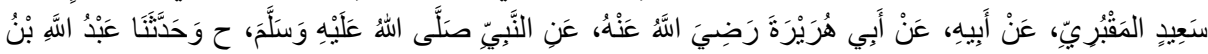

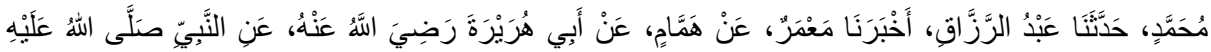

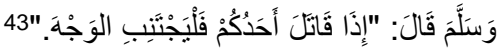

Mâlik'in talebesi İbn Vehb'den nakledilen bu rivâyet, Sahîhayn'dan önce telif edilen hadis kitaplarında Mâlik'e dayanan senedlerle bulunamamıştır.

\subsubsection{Sekizinci Rivâyet}

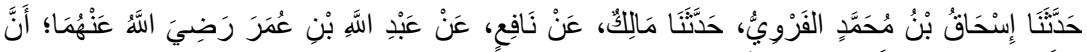

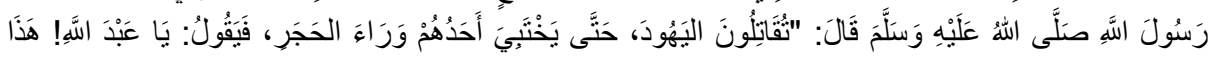

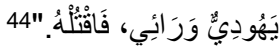

Mâlik'in talebesi İshâk b. Muhammed'den nakledilen bu rivâyet, Sahîhayn'dan önce telif edilen hadis kitaplarında Mâlik'e dayanan senedlerle bulunamamıştır.

\subsubsection{Dokuzuncu Rivâyet}

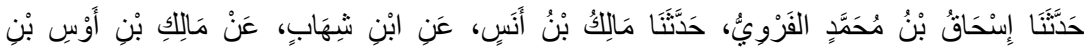

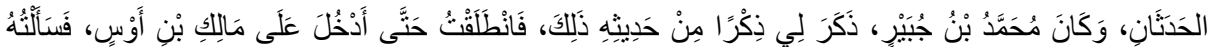

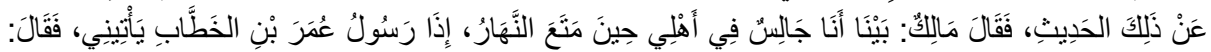

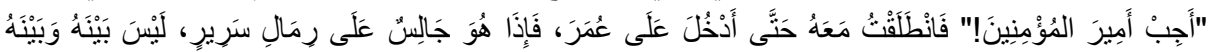

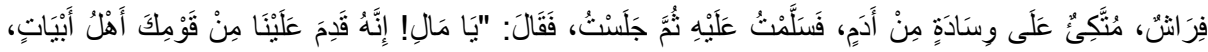

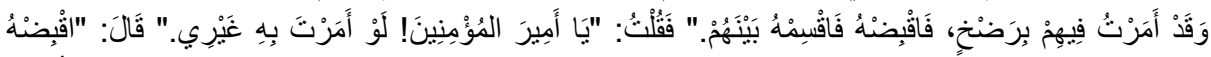

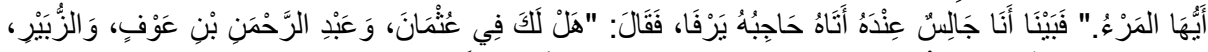

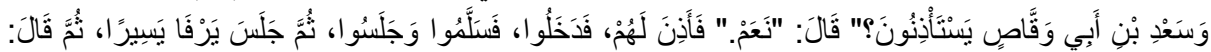

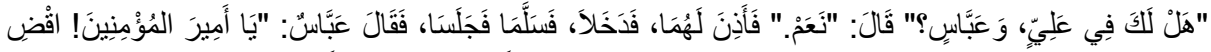

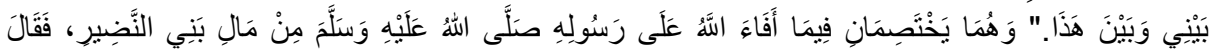

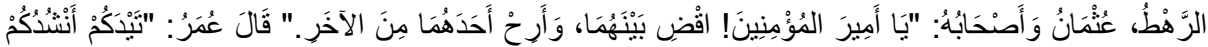

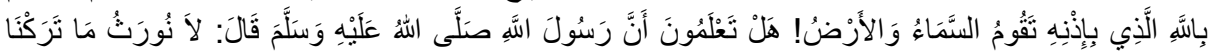

42 Ahmed b. Hanbel, Müsned, 1: 449-454 (391).

43 Buhârî, "Itk", 20 (2559).

44 Buhârî, "Cihâd”, 94 (2925). 


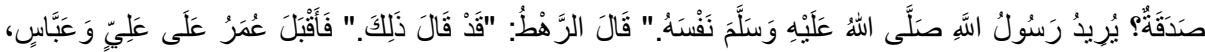

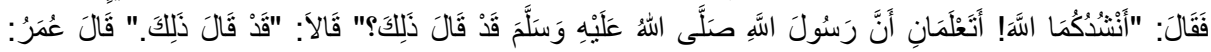

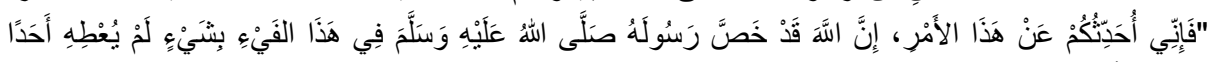

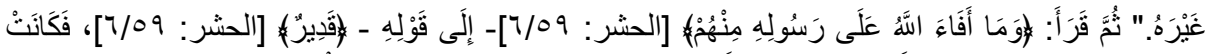

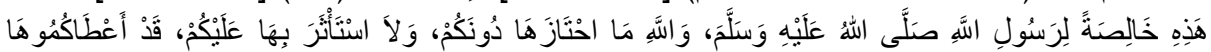

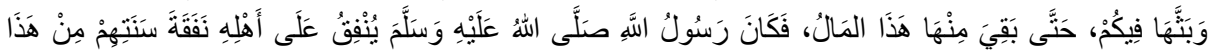

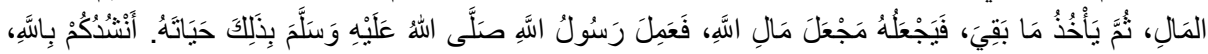

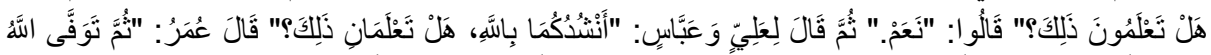

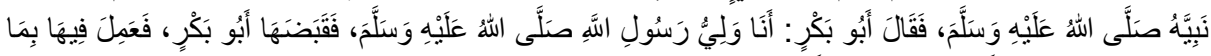

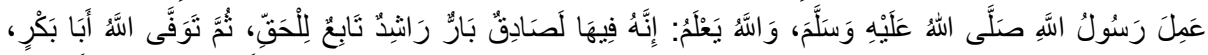

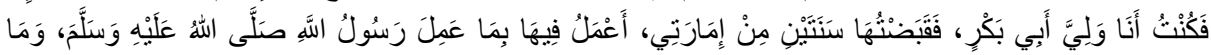

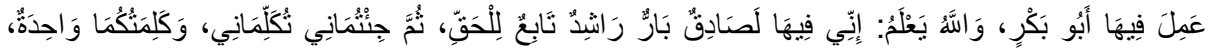

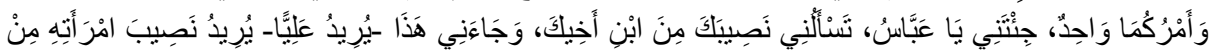

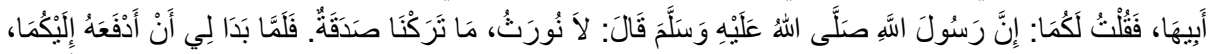

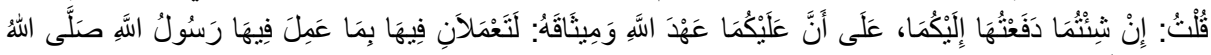

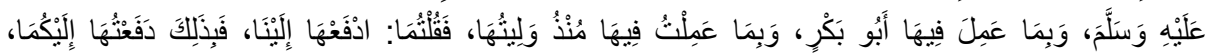

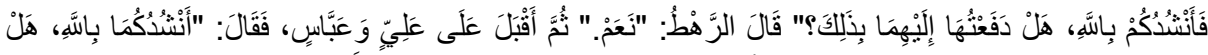

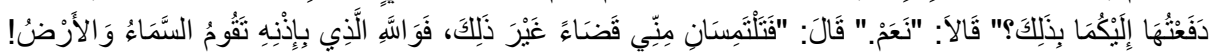

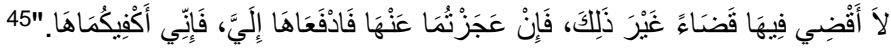

Mâlik'in talebesi İshâk b. Muhammed'den nakledilen bu rivâyet, Sahîhayn'dan önce telif edilen hadis kitaplarında bu uzun hâliyle Mâlik'e dayanan senedlerle bulunamamıştır.

\subsubsection{Onuncu Rivâyet}

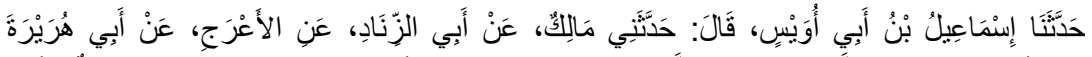

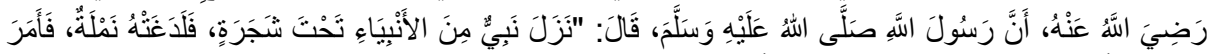

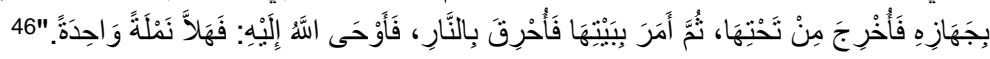

Mâlik'in talebesi İsmâîl b. Ebî Üveys'ten nakledilen bu rivâyet, Sahîhayn'dan önce telif edilen hadis kitaplarında Mâlik'e dayanan senedlerle bulunamamıştır.

\subsubsection{Onbirinci Rivâyet}

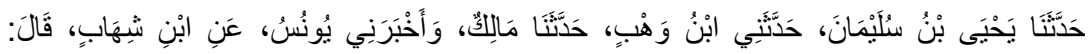

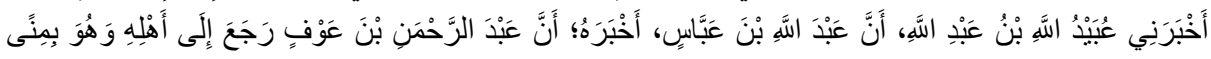

45 Buhârî, "Fardu'l-humus", 1 (3094).

${ }^{46}$ Buhârî, "Bed'ü'l-halk", 16 (3319). 


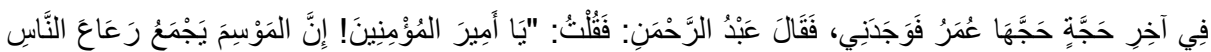

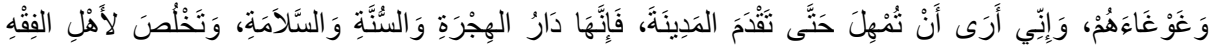

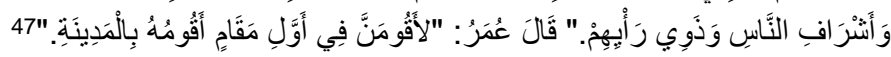

Mâlik'in talebesi İbn Vehb'den nakledilen bu rivâyet, Ahmed b. Hanbel'in Müsned'inde de aynı sened ve çok uzun bir metinle İshâk b. Îsâ tarîkiyle rivâyet edilmiştir. ${ }^{48}$ Bu uzun metnin bir bölümü 14 . hadiste geçmişti.

\subsubsection{Onikinci Rivâyet}

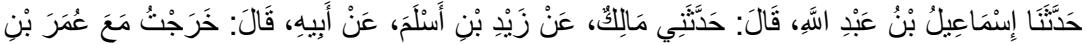

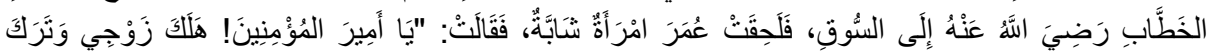

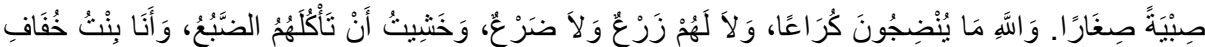

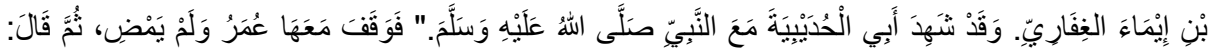

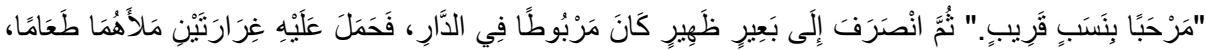

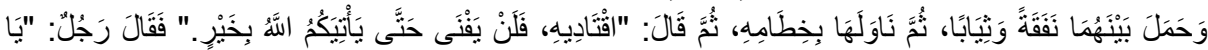

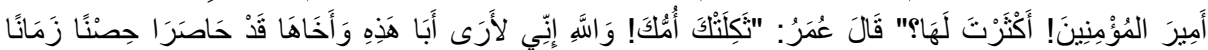

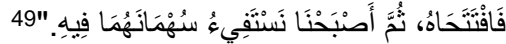

Mâlik'in talebesi İsmâîl b. Abdullâh (Ebî Üveys)'den nakledilen bu rivâyet, İbn Zenceveyh'in Emvâfinde de aynı sened ve çok benzer bir metinle yine onun tarîkiyle rivâyet edilmiştir. ${ }^{50}$

\subsubsection{Onüçüncü Rivâyet}

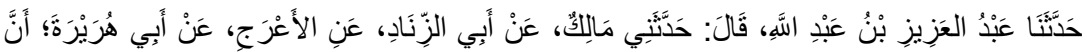

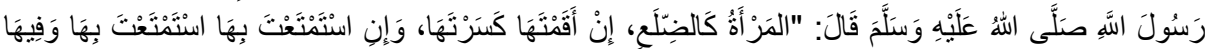
عِوَجُ.

Mâlik'in talebesi Abdülazîz b. Abdullâh'dan nakledilen bu rivâyet, Dârimî'nin Sünen'inde de aynı sened ve çok benzer bir metinle Mâlik'in talebesi Hâlid b. Mahled tarîkiyle rivâyet edilmiştir. ${ }^{52}$

\footnotetext{
47 Buhârî, "Menâkıbu'l-Ensâr", 46 (3928).

48 Ahmed b. Hanbel, Müsned, 1: 449-454 (391).

49 Buhârî, "Megâzî", 35 (4160-4161).

50 İbn Zenceveyh, Emvâl, 2: 566 (938).

51 Buhârî, "Nikâh", 80 (5184).

52 Dârimî, "Nikâh", 35 (2268).
} 


\subsubsection{Ondördüncü Rivâyet}

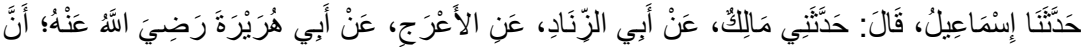

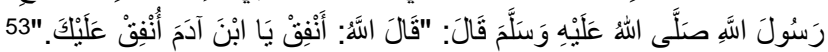

Mâlik'in talebesi İsmâîl'den nakledilen bu rivâyet, Sahîhayn'dan önce telif edilen hadis kitaplarında Mâlik'e dayanan senedlerle bulunamamıştır.

\subsubsection{Onbeşinci Rivâyet}

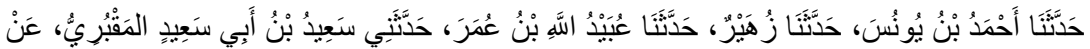

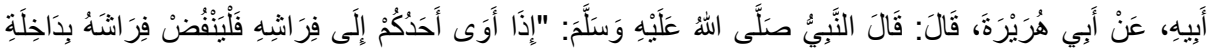

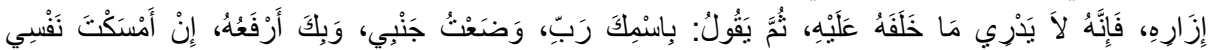

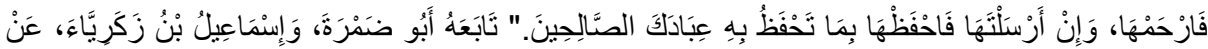

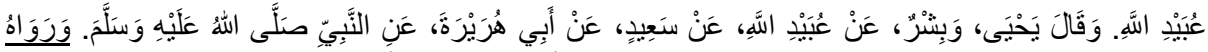

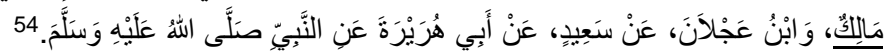

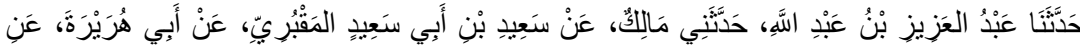

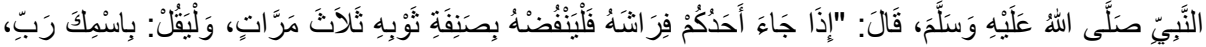

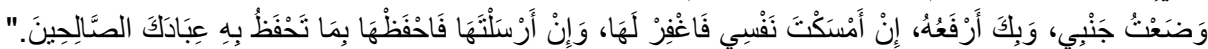

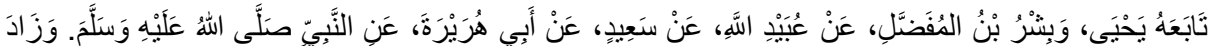

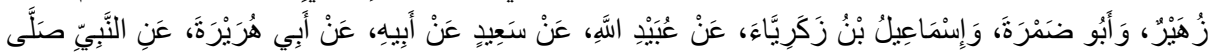

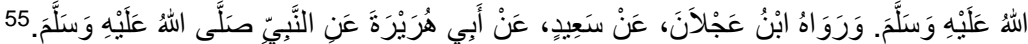

Mâlik'in talebesi Abdülazîz b. Abdullâh'tan nakledilen bu rivâyet, Sahîhayn'dan önce telif edilen hadis kitaplarında Mâlik'e dayanan senedlerle bulunamamıştır.

\subsubsection{Onaltıncı Rivâyet}

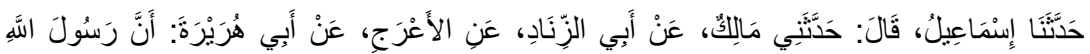

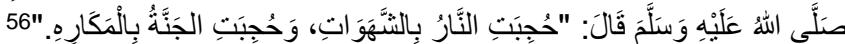

Mâlik'in talebesi İsmâîl'den nakledilen bu rivâyet, Sahîhayn'dan önce telif edilen hadis kitaplarında Mâlik'e dayanan senedlerle bulunamamıştır.

\footnotetext{
53 Buhârî, "Nafakât", 1 (5352).

54 Buhârî, "Deavât", 13 (6320).

55 Buhârî, "Tevhîd", 13 (7393).

56 Buhârî, "Rikâk", 28 (6487).
} 


\subsubsection{Onyedinci Rivâyet}

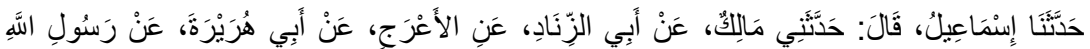

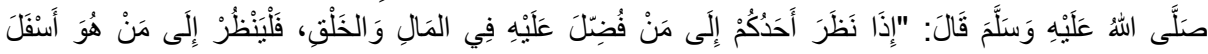
منْنُ.

Mâlik'in talebesi İsmâîl'den nakledilen bu rivâyet, Sahîhayn'dan önce telif edilen hadis kitaplarında Mâlik'e dayanan senedlerle bulunamamıştır.

\subsubsection{Onsekizinci Rivâyet}

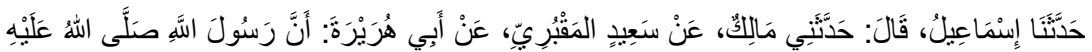

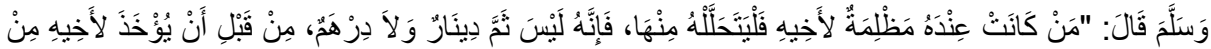

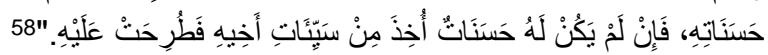

Mâlik'in talebesi İsmâîl'den nakledilen bu rivâyet, Ahmed b. Hanbel'in Müsned'inde de aynı sened ve çok benzer bir metinle Mâlik'in talebesi Yahyâ tarîkiyle rivâyet edilmiştir. ${ }^{59}$

\subsubsection{Ondokuzuncu Rivâyet}

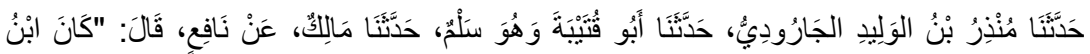

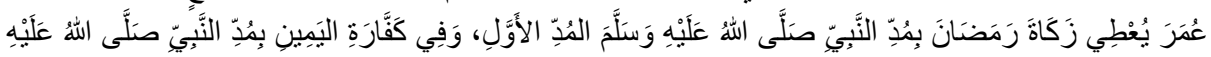

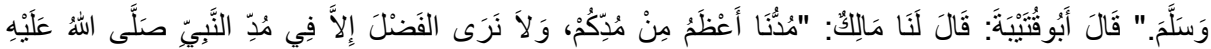

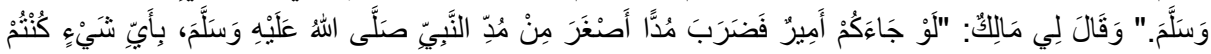

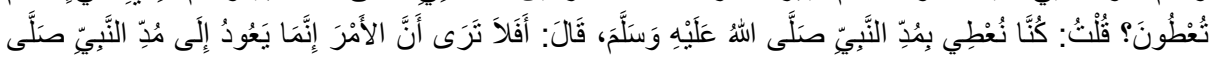
اللهُ عَلَيْهِهِ وَستَلَّ.

Mâlik'in talebesi Ebû Kuteybe'den nakledilen bu rivâyet, Sahîhayn'dan önce telif edilen hadis kitaplarında Mâlik'e dayanan senedlerle bulunamamıştır.

\subsubsection{Yirminci Rivâyet}

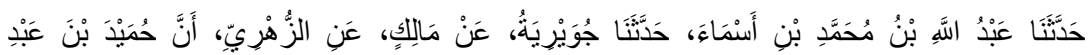

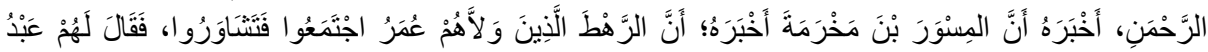

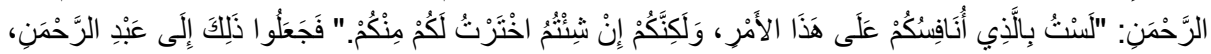

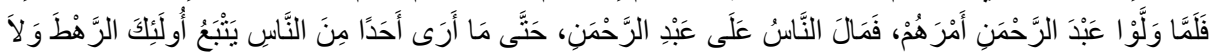

57 Buhârî, "Rikâk", 30 (6490).

58 Buhârî, "Rikâk", 48 (6534).

59 Ahmed b. Hanbel, Müsned, 15: 377 (9615).

60 Buhârî, "Keffârât", 5 (6713). 


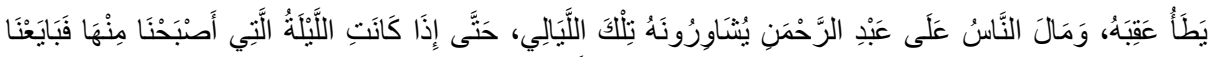

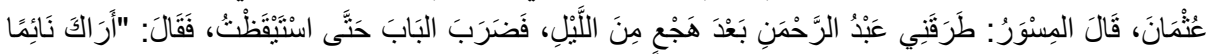

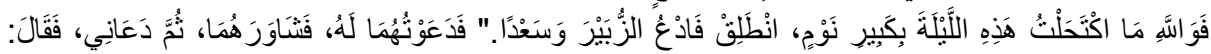

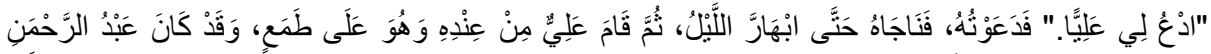

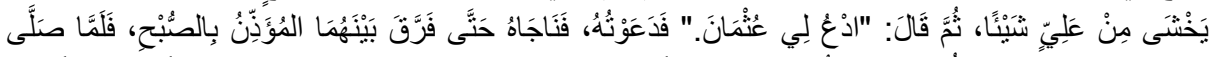

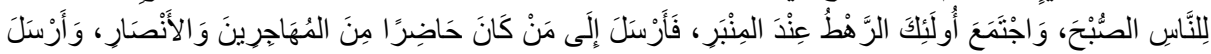

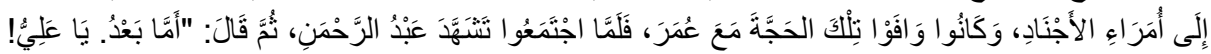

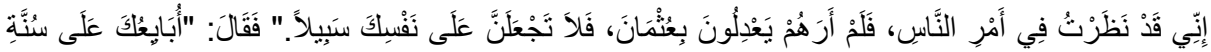

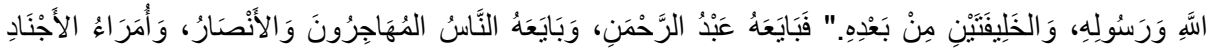
وَالمُسنْلمُونَ.

Mâlik'in talebesi Cüveyriye'den nakledilen bu rivâyet, Sahîhayn'dan önce telif edilen hadis kitaplarında Mâlik'e dayanan senedlerle bulunamamıştır.

\subsubsection{Yirmibirinci Rivâyet}

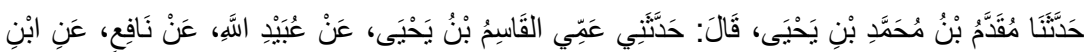

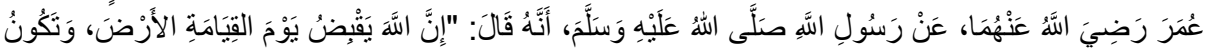

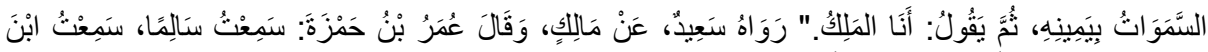

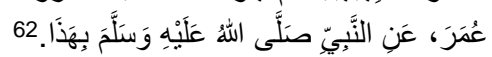

Mâlik'in de naklettiği belirtilen bu rivâyet, Sahîhayn'dan önce telif edilen hadis kitaplarında ona dayanan senedlerle bulunamamıştır.

\subsection{SADECE MÜSLIM'IN NAKLETTIGĞi RIVÂYETLER}

Şeyhayn'ın Mâlik'ten rivâyetleri kapsamında sadece Sahîh-i Müslim'de yer alan fakat mevcût ve bilinen Muvatta' nüshalarında bulunmayan 11 hadis vardır. Bu hadisler şunlardır:

\subsubsection{Birinci Rivâyet}

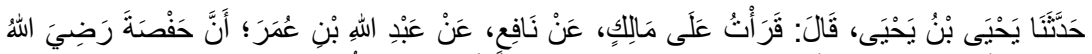

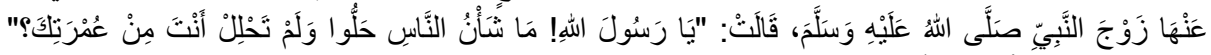

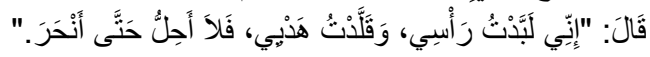

61 Buhârî, "Ahkâm", 43 (7207).

62 Buhârî, "Tevhîd", 19 (7412). 


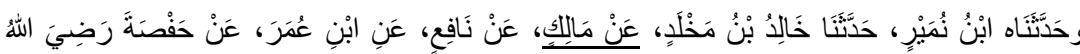

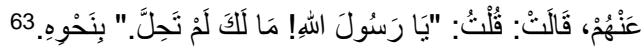

Mâlik'in talebesi Hâlid b. Mahled'den nakledilen bu rivâyet, Ahmed b. Hanbel'in Müsned'inde de aynı sened ve çok benzer bir metinle Mâlik'in talebesi İbn Mehdî tarîkiyle rivâyet edilmiştir. ${ }^{64}$

\subsection{2. İkinci Rivâyet}

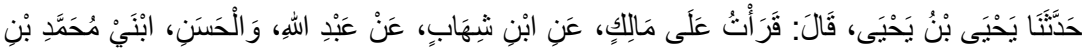

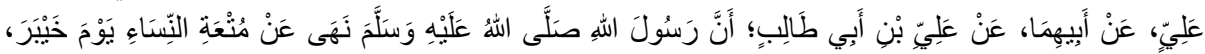

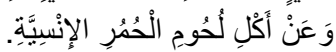

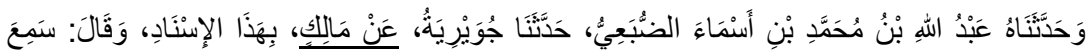

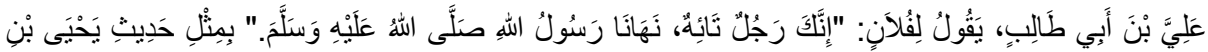
يَحْيَى، عَنْ مَالْلكِ.

Mâlik'in talebesi Cüveyriye'den nakledilen bu rivâyet, Sahîhayn'dan önce telif edilen hadis kitaplarında Mâlik'e dayanan senedlerle bulunamamıştır.

\subsection{3. Üçüncü Rivâyet}

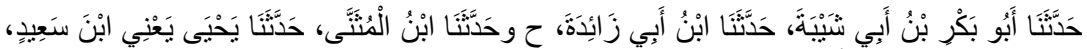

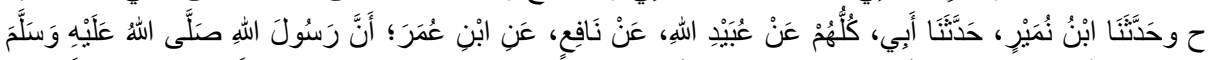

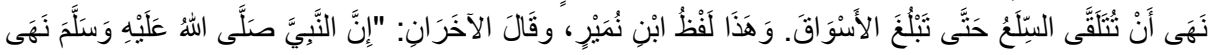
عَنِ التَلَّقِّي."

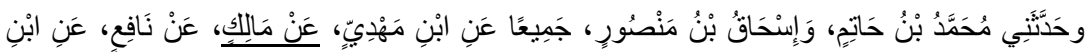

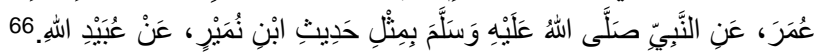

Mâlik'in talebesi İbn Mehdî'den nakledilen bu rivâyet, Sahîhayn'dan önce telif edilen hadis kitaplarında Mâlik'e dayanan senedlerle ve bu metinle

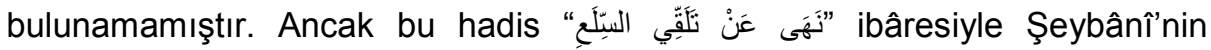
Muvatta' nüshasında yer almaktadır. ${ }^{67}$ Muhtemelen Müslim'in kastettiği rivâyet de budur. Nitekim Ahmed b. Hanbel'in belirtilen rivâyeti İbn Mehdî'den

\footnotetext{
63 Müslim, "Hac", 176 (1229).

64 Ahmed b. Hanbel, Müsned, 44: 31 (26432).

65 Müslim, "Nikâh", 29 (1407).

66 Müslim, "Büyû'”, 14 (1517).

67 Muvatta' (Şeybânî), "Buyû'”, 772.
} 
nakletmesi de bu tezi kuvvetlendirmektedir. ${ }^{68}$ Dârekutnî, bu rivâyetin Mâlik'in talebeleri İbn Ufeyr, Ma'n, Ka'nebî ve el-Velîd b. Müslim tarafından rivâyet edildiğini belirtmektedir. ${ }^{69}$

\subsubsection{Dördüncü Rivâyet}

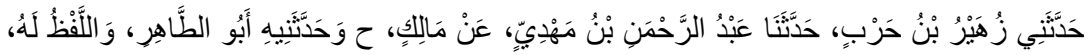

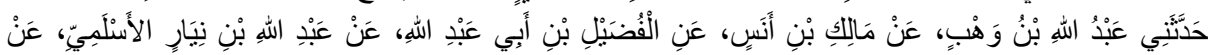

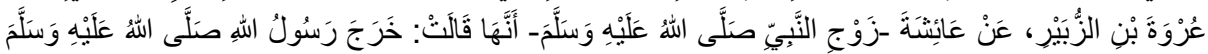

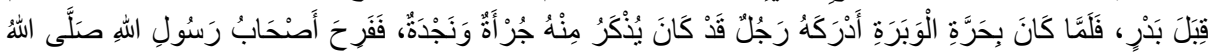

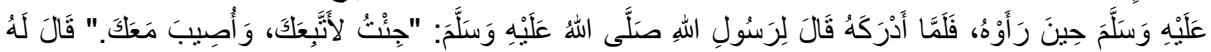

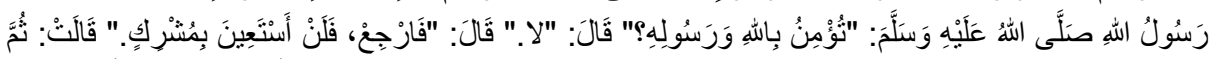

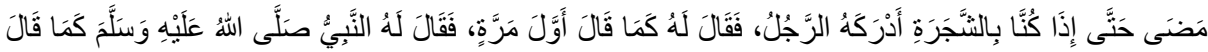

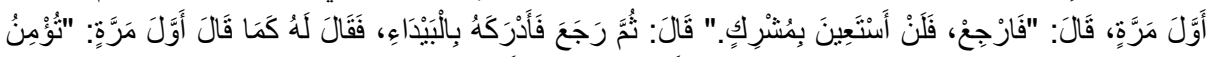

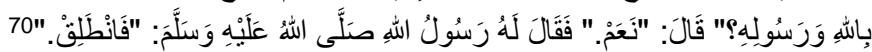

Mâlik'in talebeleri İbn Vehb (lafız ona ait) ve İbn Mehdî'den nakledilen bu rivâyet, Ahmed b. Hanbel'in Müsned'inde de aynı sened ve benzer bir metinle İbn Mehdî tarîkiyle rivâyet edilmiştir. ${ }^{71}$ Ayrıca İbn Abdilber, bu rivâyetin Muvatta'ın sadece Ma'n b. Îsâ, Saîd b. Ufeyr ve Abdullâh b. Yûsuf nüshalarında yer aldığını belirtmiştir. Naklettiği metin yukarıdakı metinle hemen hemen aynıdır. ${ }^{72}$ Dârekutnî ise, bu rivâyetin İ̉n Ufeyr ve İbn Yûsuf nüshalarında yer aldığını, Ma'n, İ̉n Mehdî, Yahyâ el-Kattân ve İbn Ebî Üveys'in Muvatta' dışında bu rivâyeti naklettiğini ifade etmektedir. ${ }^{73}$

\subsubsection{Beşinci Rivâyet}

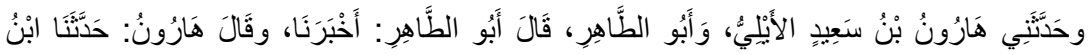

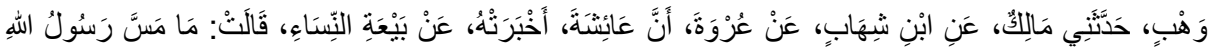

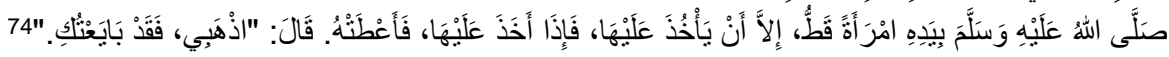

Mâlik'in talebesi İbn Vehb'den nakledilen bu rivâyet, Sahîhayn'dan önce telif edilen hadis kitaplarında Mâlik'e dayanan senedlerle bulunamamıştır.

\footnotetext{
68 Ahmed b. Hanbel, Müsned, 8: 126 (4531).

69 Dârekutnî, Ehâdîsü'l-Muvatta', 181.

70 Müslim, "Cihâd", 150 (1817).

71 Ahmed b. Hanbel, Müsned, 42: 80 (25158).

72 İbn Abdilber, et-Tekassî, 551; Cevherî, Müsnedü'l-Muvatta', 494-495.

73 Dârekutnî, Ehâdîsü'l-Muvatta', 168.

74 Müslim, "İmâre", 89 (1866).
} 


\subsubsection{Altıncı Rivâyet}

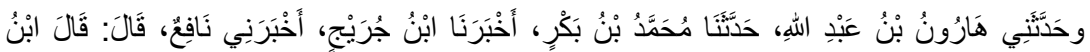

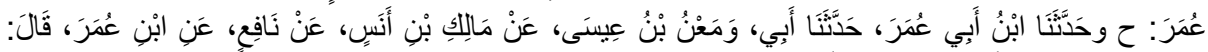

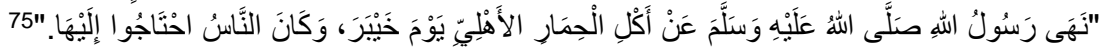

Mâlik'in talebeleri Ebû Ömer ve Ma'n'dan nakledilen bu rivâyet, Sahîhayn'dan önce telif edilen hadis kitaplarında Mâlik'e dayanan senedlerle bulunamamıştır.

\subsubsection{Yedinci Rivâyet}

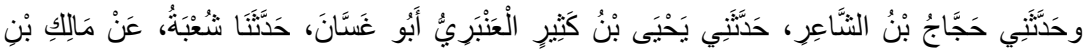

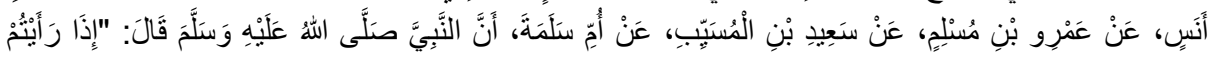

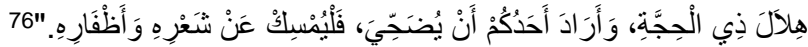

Mâlik'in talebesi Şu'be'den nakledilen bu rivâyet, Ahmed b. Hanbel'in Müsned'inde de aynı sened ve benzer bir metinle yine Şu'be'den rivâyet edilmiştir. ${ }^{77}$

\subsubsection{Sekizinci Rivâyet}

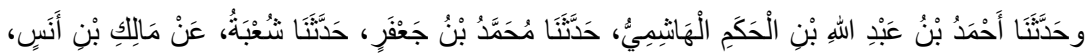

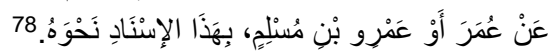

Mâlik'in talebesi Şu'be'den nakledilen bu rivâyet, Ahmed b. Hanbel'in Müsned'inde de aynı sened ve belirtilen metinle yine Şu'be'den rivâyet edilmiştir. ${ }^{79}$

\subsubsection{Dokuzuncu Rivâyet}

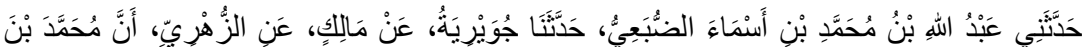

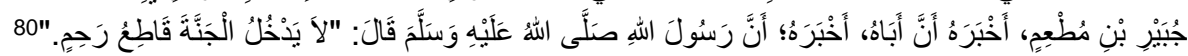

Mâlik'in talebesi Cüveyriye'den nakledilen bu rivâyet, Sahîhayn'dan önce telif edilen hadis kitaplarında Mâlik'e dayanan senedlerle bulunamamıştır.

75 Müslim, "Sayd", 25 (561).

76 Müslim, "Edâhî", 41 (1977).

77 Ahmed b. Hanbel, Müsned, 44: 258 (26654).

78 Müslim, "Edâhî", 41 (1977).

79 Ahmed b. Hanbel, Müsned, 44: 258 (26654).

80 Müslim, "Birr", 19 (2556). 


\subsubsection{Onuncu Rivâyet}

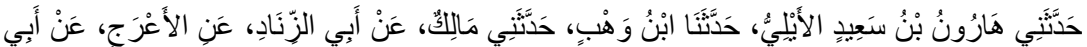

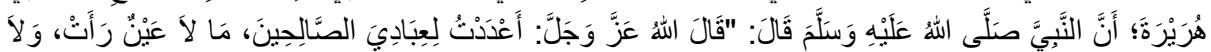

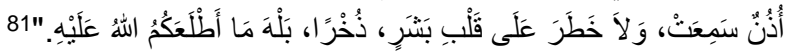

Mâlik'in talebesi İbn Vehb'den nakledilen bu rivâyet, Sahîhayn'dan önce telif edilen hadis kitaplarında Mâlik'e dayanan senedlerle bulunamamıştır.

\subsubsection{Onbirinci Rivâyet}

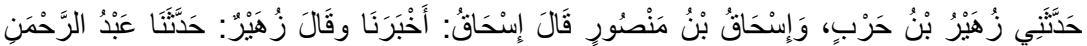

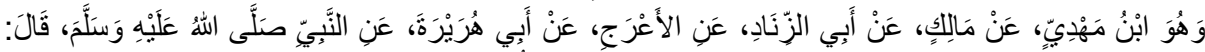

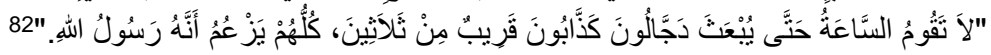

Mâlik'in talebesi İbn Mehdî'den nakledilen bu rivâyet, Ahmed b. Hanbel'in Müsned'inde de aynı sened ve metinle yine İbn Mehdî'den rivâyet edilmiştir. ${ }^{83}$

\section{RIVÂYETLERIN TAHLÎLİ}

Bir kısmı müttefekun aleyh olan bu 40 rivâyetin 32 tanesi (\% 80) merfû', 8 tanesi (\% 20) ise mevkûftur.

\begin{tabular}{|l|c|}
\hline Merfû rivâyetler & $\begin{array}{r}1,3,4,5,6,7,8,9,10,11,13,15,16,18,21,22,23,24,25,26, \\
29,30,31,32,33,34,35,36,37,38,39,40\end{array}$ \\
\hline Mevkûf rivâyetler & $2,12,14,17,19,20,27,28$, \\
\hline
\end{tabular}

Bu rivâyetlerin 39 tanesi 57 tarîkten nakledilmektedir. Rivâyetlerden biri ise muallaktır. Belirtilen 57 tarîkin Mâlik'in talebelerine göre dağılımı şöyledir:

\begin{tabular}{|c|l|c|}
\hline No & TALEBENiN isMi & $\begin{array}{c}\text { RIVÂYET } \\
\text { SAYISI }\end{array}$ \\
\hline 1 & Abdullâh b. Vehb (ö. 197/813) & 12 \\
\hline 2 & İsmâîl [b. Ca'fer] (ö. 180/796) & 85 \\
\hline
\end{tabular}

81 Müslim, "Cennet”, 3 (2824).

82 Müslim, "Fiten", 84 (157).

83 Ahmed b. Hanbel, Müsned, 12: 165 (7228).

${ }^{84}$ Mâlik'in talebelerinden olup sikadır. Ebû Abdillâh Şemsüddîn Muhammed b. Ahmed ez-Zehebî, Siyerü a'lâmi'n-nübelâ (Beyrût: Müessesetü'r-risâle, 1985) 9: 224-226. Ayrıca bk. Saffet Köse, "Ibn Vehb”, Türkiye Diyanet Vakfı İslâm Ansiklopedisi (Ankara: TDV Yayınları, 1999), 20: 441442.

${ }^{85}$ Muhaddis ve kıraat âlimi olan İsmâîl b. Ca'fer Mâlik'in talebesi olup sika bir râvîdir. Yûsuf b. Abdurrahmân el- Mizzî, Tehzîbü'l-Kemâl fî esmâi'r-ricâl (Beyrût: Müessesetü'r-risâle, 1980) 3: 5660. Ayrıca bk. Zekeriya Tüfekçioğlu, “İsmâîl b. Ca'fer el-Ensârî”, Türkiye Diyanet Vakfı İslâm 


\begin{tabular}{|c|c|c|}
\hline 3 & Cüveyriye b. Esmâ (ö. 173/789) $)^{86}$ & 7 \\
\hline 4 & Abdurrahmân b. Mehdî (ö. 198/814) $)^{87}$ & 6 \\
\hline 5 & Ma'n [b. Îsâ] (ö. 198/814) $)^{88}$ & 6 \\
\hline 6 & Abdülazîz b. Abdullâh [el-Üveysî] (ö. 220?/835?) ${ }^{89}$ & 4 \\
\hline 7 & Şu'be [b. Haccâc] (ö. 160/776) & 2 \\
\hline 8 & İshâk b. Muhammed el-Fervî (ö. 226/841) $)^{91}$ & 2 \\
\hline 9 & İsmâîl b. Abdullâh [Ebû Üveys] (ö. 226/841) ${ }^{92}$ & 2 \\
\hline 10 & Abdullâh b. Yûsuf [et-Tennîsî](ö. 218/833) & 1 \\
\hline 11 & İshâk b. Îsâ (ö. 224/839) ${ }^{94}$ & 1 \\
\hline 12 & Abdullâh b. el-Mübârek (ö. 181/797) ${ }^{95}$ & 1 \\
\hline 13 & Ebû Kuteybe Selm [b. Kuteybe] (ö. 200/815) & 1 \\
\hline 14 & [Yahyâ b.] Ebû Ömer (ö. ? ?) & 1 \\
\hline 15 & Hâlid b. Mahled (ö. 213/828) ${ }^{98}$ & 1 \\
\hline
\end{tabular}

Ansiklopedisi (Ankara: TDV Yayınları, 2001), 23: 90-91.

${ }^{86}$ Mâlik'ten rivâyette bulunan sika bir râvîdir. Zehebî, Siyerü a'lâmi'n-nübelâ, 7: 317-318.

87 Mâlik'in talebelerinden olup sikadır. Mizzî, Tehzîbü'l-Kemâl, 17: 430-443.

${ }^{88}$ Mâlik'in talebelerinden olup sikadır. Zehebî, Siyerü a'lâmi'n-nübelâ, 9: 305, 10: 689. Ayrıca bk. Orhan Çeker, "Ma'n b. Îsâ", Türkiye Diyanet Vakfı İslâm Ansiklopedisi (Ankara: TDV Yayınları, 2003), 27: 555.

${ }^{89}$ Mâlik'in talebelerinden olup sikadır. Zehebî, Siyerü a'lâmi'n-nübelâ, 10: 389.

${ }^{90}$ Şu'be, Mâlik'in akranlarından olan bir hadis imâmıdır. Bk. Zehebî, Siyerü a'lâmi'n-nübelâ, 7: 202-205. Ayrıca bk. İbrahim Hatiboğlu, "Şu'be b. Haccâc", Türkiye Diyanet Vakfı İslâm Ansiklopedisi (Ankara: TDV Yayınları, 2010), 39: 224-226.

${ }^{91}$ Mâlik'in talebelerindendir. Zehebî Fervî için, imâm, muhaddis ve âlim demektedir. Ebû Hâtim, onun sadûk olduğunu fakat gözlerini kaybettiğini, bazen rivâyetleri konusunda yönlendirilebildiğini, bununla birlikte yazdıklarının sahîh olduğunu söylemektedir. İbn Hibbân onu sikalar arasında saymakta, Ebû Dâvûd ve Dârekutnî ise zayıf bir râvî olduğunu kaydetmektedir. Zehebî, Siyerü a'lâmi'n-nübelâ, 10: 649-650.

${ }_{92}$ Mâlik'in talebelerin olup biraz zayıf bir râvîdir. Zehebî, Mîzânü'l-i'tidâl fî nakdi'r-ricâl (Beyrût: Dârü'l-ma'rife, 1963), 1: 222. Ayrıca bk. İsmail Hakkı Ünal, "İsmâîl b. Ebû Üveys", Türkiye Diyanet Vakfı Islâm Ansiklopedisi (Ankara: TDV Yayınları, 2001), 23: 95.

${ }^{93}$ Mâlik'in önde gelen talebelerinden olup sikadır. Bk. Zehebî, Siyerü a'lâmi'n-nübelâ, 10: 357358.

${ }^{94}$ Mâlik'in talebelerindendir. Onun hakkında; Buhârî "meşhûrü'l-hadîs", Sâlih b. Muhammed "lâ be'se bih, sadûk", Ebû Hâtim ise "sadûk" demiștir. Bk. Mizzî, Tehzîbü'l-Kemâl, 2: 462-464.

95 Mâlik'in talebelerinden sika bir râvîdir. Mizzî, Tehzîbü'l-Kemâl, 8: 379. Ayrıca bk. Raşit Küçük, "Abdullâh b. Mübârek", Türkiye Diyanet Vakfı İlâm Ansiklopedisi (Ankara: TDV Yayınları, 1988), 1: $122-124$

96 Mâlik'in talebesi olan Ebû Kuteybe, Ebû Dâvûd ve Ebû Zür'a'ya göre sikadır. Ancak Yahyâ b. Maîn ve Ebû Hâtim, onun için "lâ be'se bih" hükmü vermiş, ayrıca Ebû Hâtim onun çok vehmettiğini ama hadislerinin yazılabileceğini söylemiştir. Mizzî, Tehzîbü'l-Kemâl, 11: 232-235.

97 Mâlik'in talebelerindendir. Hakkında yeterli bilgi bulunmamaktadır. Bk. Mizzî, Tehzíbü'l-Kemâl, 31: 476; İbn Hacer (Ahmed b. Ali el-Askalânî), Tehzîbü't-Tehzîb, (Hindistan: Matbaatü dâireti'lmeârif, 1326), 11: 260.

98 Mâlik'in talebelerindendir. Ahmed b. Hanbel, münker hadisler naklettiğini belirtmiştir. Yahyâ b. Maîn, onun hakkında "mâ bihî be's" demiştir. Ebû Hâtim ise hadislerinin yazılabileceği kanaatindedir. Ebû Dâvûd, sadûk fakat Şiî olduğunu ifade etmiştir. Bk. Mizzî, Tehzîbü'l-Kemâl, 8: 163-165. 
Bu 16 talebenin 12 tanesi güvenilir, 3 tanesi zayıftır. 1 talebenin durumu hakkında ise yeterli bilgi bulunamamıştır. Bu râvîlerin güvenilirlik açısından oranları aşağıdaki tabloda gösterilmiştir.

\begin{tabular}{|c|c|c|}
\hline GÜVENILIRLIK DURUMU & SIRA NO & ORAN \\
\hline Güvenilir talebeler & $1,3,4,5,6,7,10,11,12,14,15$ & $\% 80$ \\
\hline Zayıf talebeler & $8,9,16$ & $\% 20$ \\
\hline
\end{tabular}

Matbû' Muvatta' nüshalarında yer almayan bu 40 rivâyetin, Sahîhayn müelliflerinden önce vefât eden muhaddislerin eserlerinde Mâlik'ten rivâyetler şeklinde yer alan 16 tanesinin müelliflere göre dağılımı ve oranları şöyledir:

\begin{tabular}{|c|l|c|c|c|}
\hline No & MUHADDisin iSMi & RIVÂYET SAYISI & RIVÂYETLER & ORAN \\
\hline 1 & $\begin{array}{l}\text { Ahmed b. Hanbel } \\
\text { (ö. 241/855) }\end{array}$ & 13 & $\begin{array}{c}2,5,8,12,14,19, \\
26,30,32,33,36, \\
37,40\end{array}$ & $\% 33$ \\
\hline 2 & $\begin{array}{l}\text { Abd b. Humeyd } \\
\text { (ö. 249/863) }\end{array}$ & 1 & 13 & $\% 2,5$ \\
\hline 3 & $\begin{array}{l}\text { İbn Zenceveyh } \\
\text { (ö. 251/865) }\end{array}$ & 1 & 20 & $\% 2,5$ \\
\hline 4 & $\begin{array}{l}\text { Dârimî } \\
\text { (ö. 255/869) }\end{array}$ & 1 & 21 & $\% 2,5$ \\
\hline
\end{tabular}

Matbû' Muvatta' nüshalarında bulunmayan 40 rivâyetin konularına göre dağılımı anahatlarıyla şöyledir:

\begin{tabular}{|c|c|c|c|}
\hline KONU & SAYI & RIVÂYET NO & ORAN \\
\hline İlim & 1 & 2 & $\% 2,5$ \\
\hline Kıyâmet & 10 & $1,3,6,8,16,24,26,29,39,40$ & $\% 25$ \\
\hline İbâdet & 5 & $10,27,30,36,37$ & $\% 12,5$ \\
\hline Fedâil & 5 & $4,5,9,22,23$ & $\% 12,5$ \\
\hline Hukûk & 12 & $12,14,15,17,19,20,28,31,32,33,34,35$ & $\% 30$ \\
\hline Ahlâk & 7 & $7,11,14,18,21,25,38$ & $\% 17,5$ \\
\hline
\end{tabular}

99 Saîd zayıf bir râvîdir. Hakkında Ebû Hâtim, "Muvatta'yı rivâyet eder, kavî değildir", Yahyâ b. Maîn "Bana göre sika değildir", Ebû Zur'a ise "zayıftır" demektedir. Zehebî, Saîd'i 211-220 hicrî yılları arasında vefât edenler arasında zikretmektedir. Bk. Zehebî, Târîhü'l-Islâm (Beyrût: Dârü'lkitâbi'l-Arabî, 1991), 15: 168. 


\section{SONUÇ}

Buhârî ve Müslim, el-Câmi'u's-sahîh'lerinde İmâm Mâlik'ten yüzlerce hadis rivâyet etmektedir. Bu rivâyetlerin çok büyük bir kısmı Muvatta'ın en meşhûr nüshası olan Yahyâ b. Yahyâ el-Leysî rivâyetinde yer almaktadır. Geriye kalan az sayıdaki rivâyetin çoğunluğu da diğer nüshalarda bulunabilmektedir. Toplam $768(416+352)$ rivâyetin sadece $48(29+19)$ tanesi matbû' Muvatta' nüshalarında bulunmamaktadır. Bu sayı toplam rivâyetin yaklaşık \% 6'sını oluşturmaktadır.

Muvatta' gibi 1000 'den fazla râvîsi olan ${ }^{100}$ bir eserin farklı nüshalarına ve bu nüshalardan rivâyette bulunan talabelere Mâlik'ten çok da geç bir zamanda yaşamayan Buhârî ve Müslim döneminde ulaşılabilmekteydi. ${ }^{101}$ Dolayısıyla Buhârî ve Müslim'in, bu nüshalardan rivâyette bulunan muhaddislerden istifâde etmesi ve Mâlik'in Muvatta' dışındaki rivâyetlerine kitaplarında yer vermesi gayet doğal bir durumdur.

Muvatta'ın tüm nüshaları günümüze ulaşamadığı için burada zikredilen 40 rivâyetten ne kadarının o nüshalarda yer aldığını kaç tanesinin diğer rivâyetlerden oluştuğunu tam olarak tespit etmek mümkün değildir. Ancak Ibn Abdilber, Cevherî ve Dârekutnî gibi çok sayıda Muvatta' nüshasını inceleme imkânı bulmuş muhaddislerin nüsha karşılaştırmaları esas alındığında bu 40 rivâyetten sadece 2 tanesinin (13 ve 33. rivâyetler) diğer nüshalarda yer aldığı, kalan 38 rivâyetin ise muhtemelen Mâlik'in Muvatta'ı dışındaki rivâyetlerinden alındığı gibi bir sonuç ortaya çıkmaktadır. Bu durum, Buhârî ve Müslim gibi büyük muhaddislerin Mâlik'in sadece Muvatta'ından faydalanmadığını göstermektedir. Dolayısıyla buradaki rivâyetler, Mâlik'in Muvatta' dışındaki rivâyetlerinin en azından bir kısmını öğrenme açısından da kaynak teşkil etmektedir.

Son söz olarak; bütün bunlardan hareketle İmâm Mâlik'in günümüze ulaşan rivâyetlerini sadece Muvatta' nüshalarında araştırmanın yeterli olmadığı, kendisinden rivâyette bulunan muhaddislerin eserlerindeki rivâyetlerin de derlenmesi gerektiği, daha sonra Muvatta' nüshalarındaki

\footnotetext{
100 Kandemir, M. Yaşar, "Muvatta", Türkiye Diyanet Vakfı İslâm Ansiklopedisi (Ankara: TDV Yayınları, 2006), 31: 416.

101 Zehebî, Mâlik'i 5, Buhârî̀yi 9 ve Müslim'i 10. tabaka muhaddisler arasında saymaktadır. Bk. Ebû Abdillâh Şemsüddîn Muhammed b. Ahmed ez-Zehebî, el-Muîn fî tabakâti'l-muhaddisîn (Beyrût: Dârü'l-kütübi'l-ilmiyye, 1998), 60, 95, 105.
} 
rivâyetlerle bu rivâyetlerin birleştirilmesiyle oluşturulacak çalışmanın Mâlik'in merviyyâtı hakkında daha çok bilgi vereceği belirtilmelidir. 


\section{KAYNAKÇA}

Aytekin, Arif. "İbn Tûmert”. Türkiye Diyanet Vakfı İslâm Ansiklopedisi (Ankara: TDV Yayınları, 1999), 20: 425-427.

Buhârî, Ebû Abdillâh Muhammed b. İsmâîl. Șahîhü̈'l-Buhârî. Kâhire: Dârü'l-hadîs, 2011.

Cevherî, Abdurrahmân b. Abdullâh. Müsnedü'I-Muvatta'. Beyrût: Dârü'lgarbi'l-İslâmî, 1997.

Çeker, Orhan. "Ma'n b. Îsâ". Türkiye Diyanet Vakfı İslâm Ansiklopedisi (Ankara: TDV Yayınları, 2003), 27: 555.

Dârekutnî, Ali b. Ömer. Ehâdîsü'I-Muvatta'. Şârika: Mektebetü ehli'lhadîs, ts.

Dârimî, Abdullâh b. Abdrurrahmân. Müsnedü'd-Dârimî (Sünenü'dDârimî). Suûdî Arabistan: Dârü'l-muğnî, 2000.

Durmuş, Üzeyir. “İmam Müslim'in Sahîh'ine Kaynaklık Bakımından İmam Mâlik'in Muvatta'sı (Tahrîc, Mukâyese ve Tahlîl)". Abant Izzet Baysal Üniversitesi Illahiyat Fakültesi Dergisi 6/11 (Haziran 2018), 58-90.

Hanbel, Ahmed b. Muhammed b. Hanbel. Müsned. Beyrût: Müessesetü'r-risâle, 2001.

Hatiboğlu, İbrahim. "Şu'be b. Haccâc". Türkiye Diyanet Vakfı İslâm Ansiklopedisi (Ankara: TDV Yayınları, 2010), 39: 224-226.

Humeyd, Abdülhamîd b. Humeyd, el-Müntehab min Müsnedi Abd b. Humeyd. (Kâhire: Mektebetü's-sünne, 1988).

İbn Abdilberr, Yûsuf b. Abdilberr en-Nemerî. et-Tekassî. Kuveyt: elVa'yü’l-İslâmî, 2012.

İbn Hacer, Ahmed b. Ali el-Askalânî. Tehzîbü't-Tehzîb. Hindistan: Matbaatü dâireti'l-meârif, 1326. 
Kandemir, M. Yaşar, "Muvatta", Türkiye Diyanet Vakfı İslâm Ansiklopedisi (Ankara: TDV Yayınları, 2006), 31: 416-418.

Köse, Saffet. "İbn Vehb”. Türkiye Diyanet Vakfı İslâm Ansiklopedisi (Ankara: TDV Yayınları, 1999), 20: 441-442.

Küçük, Raşit. "Abdullâh b. Mübârek”. Türkiye Diyanet Vakfı İslâm Ansiklopedisi (Ankara: TDV Yayınları, 1988), 1: 122-124.

Mâlik b. Enes, el-Muvatta' (Abdullâh b. Mesleme el-Ka'nebî rivâyeti), Thk. Abdülmecîd Türkî, Beyrût: Dârü'l-garbi'l-İslâmî, 1999.

Mâlik b. Enes, el-Muvatta' (Abdullâh b. Vehb rivâyeti), Thk. Mikloş Muranyi, Beyrût: Dârü'l-garbi'l-İslâmî, 2002.

Mâlik b. Enes, el-Muvatta' (Abdurrahmân b. Kâsım rivâyeti/Kâbisî, elMulahhas li Müsnedi'I-Muvatta), Ali İbrâhîm Mustafâ, Beyrût: Dârü'l-kütübi'lilmiyye, 2008.

Mâlik b. Enes, el-Muvatta' (Ali b. Ziyâd el-Absî rivâyeti), Thk. Muhammed el-Şâzelî en-Nüfeyr, Beyrût: Dârü'l-garbi'l-İslâmî, 1980.

Mâlik b. Enes, el-Muvatta' (Ebû Mus'âb ez-Zührî rivâyeti), Thk. Beşşâr Avvâd Ma'rûf ve Mahmûd Muhammed Halîl, Beyrût: Müessesetü'r-risâle, 1998.

Mâlik b. Enes, el-Muvatta' (Muhammed b. Hasan eş-Şeybânî rivâyeti), Thk. Abdülvehhâb Abdüllatîf, Kâhire: Lecnetü ihyâi't-türâs, 1994.

Mâlik b. Enes, el-Muvatta' (Süveyd b. Saîd el-Hadesânî rivâyeti), Thk. Abdülmecîd Türkî, Beyrût: Dârü'l-garbi'l-İslâmî, 1994.

Mâlik b. Enes, el-Muvatta' (Yahyâ b. Yahyâ el-Leysî rivâyeti), Thk. Muhammed Fuâd Abdülbaki, Kâhire: Dârü'l-hadîs, 2005.

Mizzî, Yûsuf b. Abdurrahmân. Tehzîbü'l-Kemâl fî esmâi'r-ricâl. Beyrût: Müessesetü'r-risâle, 1980. 
Müslim, Ebü'l-Hüseyn Müslim b. el-Haccâc. Șahịhü Müslim. Beyrût: Dârü'l-kütübi'l-ilmiyye, 2011.

Özel, Ahmet, "Mâlik b. Enes", TDV İslâm Ansiklopedisi (DIA), XXVII, 506-513.

Sezgin, Fuad, Buhârînnin Kaynakları, İstanbul: İbrahim Horoz Basımevi, 1956.

Sifil, Ebubekir, Muvatta Nüshaları Muhteva Analizi, İstanbul: Rihle Kitap, 2017.

Tüfekçioğlu, Zekeriya. "İsmâîl b. Ca'fer el-Ensârî". Türkiye Diyanet Vakfı İslâm Ansiklopedisi (Ankara: TDV Yayınları, 2001), 23: 90-91.

Ünal, İsmail Hakkı. "İsmâîl b. Ebû Üveys Türkiye Diyanet Vakfı İslâm Ansiklopedisi (Ankara: TDV Yayınları, 2001), 23: 95.

Zehebî, Ebû Abdillâh Şemsüddîn Muhammed b. Ahmed. Mîzânü'li'tidâl fî nakdi'r-ricâl. Beyrût: Dârü'l-ma'rife, 1963.

Zehebî, Ebû Abdillâh Şemsüddîn Muhammed b. Ahmed. el-Muîn fî tabakâti'l-muhaddisîn. Beyrût: Dârü'l-kütübi'l-ilmiyye, 1998.

Zehebî, Ebû Abdillâh Şemsüddîn Muhammed b. Ahmed. Siyerü a'lâmi'n-nübelâ. Beyrût: Müessesetü'r-risâle, 1985.

Zehebî, Ebû Abdillâh Şemsüddîn Muhammed b. Ahmed, Târîhü'IIslâm, Beyrût: Dârü'l-kitâbi'l-Arabî, 1991.

Zenceveyh, Humeyd b. Mahled. el-Emvâl. Suûdî Arabistan: Merkezü Melik Faysal, 1986. 


\title{
A Research on The Narrations of Sahīhain That Narrated From Imām Mālik Which is Not Included in The Printed Copies of Muwața
}

Citation / @-- Durmuş, Ü. (2018). A Research on the Narrations of Sahīhain that Narrated from Imām Mālik which is not Included in the Printed Copies of Muwațta, Cukurova University Journal of Faculty of Divinity, 18 (2), 796-824.

\begin{abstract}
Muwatța of Imām Mālik and his other narrations not included in Muwatța are the important sources of the al-Jāmi as-șahịḥ's Bukhārī and Muslim. Bukhārī narrated 416 narrations from Mālik without repitition, yet Muslim narrated 352. And 29 narrations of Bukhārī and 19 narrations of Muslim are not included in the printed copies of Muwatta. Eight of these narrations are muttafakun alayh; 21 of them are only narrated by Bukhārī, and 11 of them are only narrated by Muslim. In this article, it is attempted to determine whether these narrations were found in the copies of Muwatta which is unavailable today and whether these narrations were narrated by the muhaddiths who lived before Bukhārī and Muslim. As a result of the research, it is determined that these narrations were narrated from 16 different students of Mālik, 38 of them are not included in the known copies of Muwatța, 16 of them were narrated by the muhaddiths before Mālik, 32 of them are marfü'; 8 of them are mawkūf, and that they were composed of hadiths related to various subjects. In addition all these, findings are indicated in tables. Thus, this research tries to reveal a dimension of the relationship between Sahihain and Muwața in particular and the relationship between Sahinain and Mālik's other narrations in general.
\end{abstract}

Keywords- Hadith, Bukhārī, Muslim, Mālik, al-Jāmi as-șahị̣̂, al-Muwațta. 